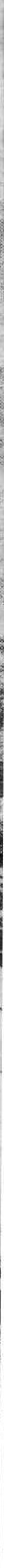

\title{
REPORT ON THE AFGHAN PAMIR
}

\author{
PART 2: BIOLOGY OF MARCO POLO SHEEP
}


Cover: The head of Tila Bai Valley in the Big Pamir (etream elevation $4680 \mathrm{~m}$ ). Photo by R.G. Petocz. 
National Parks and Utilization of Wildlife Resources

Part 2: Biology of Marco Polo Sheep (Ovis ammon poli)

\author{
Prepared by \\ Ronald G. Petocz \\ Wildlife Biologist and Team Leader, FAO \\ Khushal Habibi \\ Biologist, Department of Forests and Range \\ Ministry of Agriculture
}
Abdul Jamil
National Parks Officer, Department of Forests and Range Ministry of Agriculture
Abdul Wassey
National Parks Officer, Department of Forests and Range Ministry of Agriculture

UNITED NATIONS DEVELOPMENT PROGRAMME

FOOD AND AGRICULTURE ORGANIZATION OF THE UNITED NATIONS

DEPARTMENT OF FORESTS AND RANGE, MINISTRY OF AGRICULTURE 


\section{INTIE OF CONTEANTS}

ABSTRACT

1. INTRODUCTION

2. STATIMENT OF WORK ACCOMPLISHED 2

3. METHODS 2

4. DISTRIBUTION AND MOVEMUENTS 3

5. POPULATION CHARACTERISTICS 5

5.1. Population Size 5

5.2. Population Dymamics and Quality . 7

6. HABITAT UTILIZATION 16

6.1. Division of Habitats 16

6.2. Habitat Preferences of Marco Polo Sheep 17

6.3. Seasonal Variations in Habitat Utilization 16

6.4. Comparison of Habitat Preferences of Wild Sheep and Ibex 21

6.5. Spatial Distribution of Wild Sheep 22

7. ACTIVITY PATTERNS 23

7.1. Methods 23

7.2. Results 24

8. SELECTED COMMENTS ON THE SOCIAL BEHAVIOR OF MARCO POLO SHEEP 27

8.1. Results 27

8.1.1. Group Structure 27

8.1.2. Notes on the Rutting Behavior of Marco Polo Sheep 28

9. HORN MORPHOLOGY OF RAMS 30

10. PREDATION 32

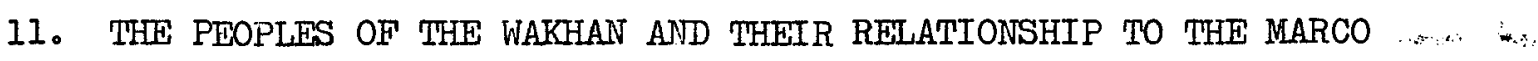

POIO SHEEP 
11.1. Distribution

11.2. The Wakhi People

34

11.3. The Kirghiz People

35

11.4. Hunting by Local People 36

12. DISCUSSION

REF'ERENCES 


\section{FIGURES}

1. Location map of the Wakhan Corridor and Pamir Mountains.

2. Distribution and movements of Marco Polo sheep in the Afghan Pamir.

3. Habitat preference of Marco Polo sheep females and followers during the months of August, September, October, December and January.

4. Habitat preference of Marco Polo sheep rams during the months of August, September, October, December and January.

5. Habitat preference of Marco Polo sheep groups during the months of August, Scptember, Octoiser, December and January.

6. Cumulative general preference index for Pamir habitats by Marco Polo sheep over a five-month period.

7. Sedge meadows in the periglacial habitat of Abalchen Valley in the Big Pamir Wildlife Reserve.

8. Proferred habitat of female Marco Polo sheep groups in auturn.

9. Oumulative general preference index for Pamir habitats by Siberiain ibex over a five-month period.

10. Grazing activity patterns of Marco Polo sheep for the months of September, October, Decomber and January.

11. Percent distribution of group sizes of Marco Polo sheep from late summer through the rut.

12. Pcroent composition of Marco Polo sheep groups from late summer through the rut.

13. A oomparison of the typical and atypical varieties of Marco Polo ram horns.

14. Horm attenuation on a seven-year-old ram.

15. Another example of horns of a mature Marco Polo ram, extremely shortened by attenuation.

16. A five-year-old ram killed by wolves on the snow-covered pass of the Jaman Sor rutting area.

17. Division of the traditional territories of Valchi and Kirghiz peopIe in the Afghan Pamir. 


\section{TABLES}

1. Results of the 1973 Maroo Polo sheep census in the Afghan Pamir.

2. Maximum number of rams observed on the Ortobil-Jaman Sor rutting area during the winter of 1974-1975.

3. Composition and mortality of Marco Polo rams in the Big Pamir Wildife Reserve and the Small Pamir.

4. Lamb production and survival in the Big Pamir Wildlife Reserve and the Small Famir.

5. Results of suckling behavior for lambs in the Big and Small Pamir.

Photographs: R.G. Petocz

Drafting: A. Farazan, N. Farmand, H. Sedigi and L. Asghari, Institute of Environment 


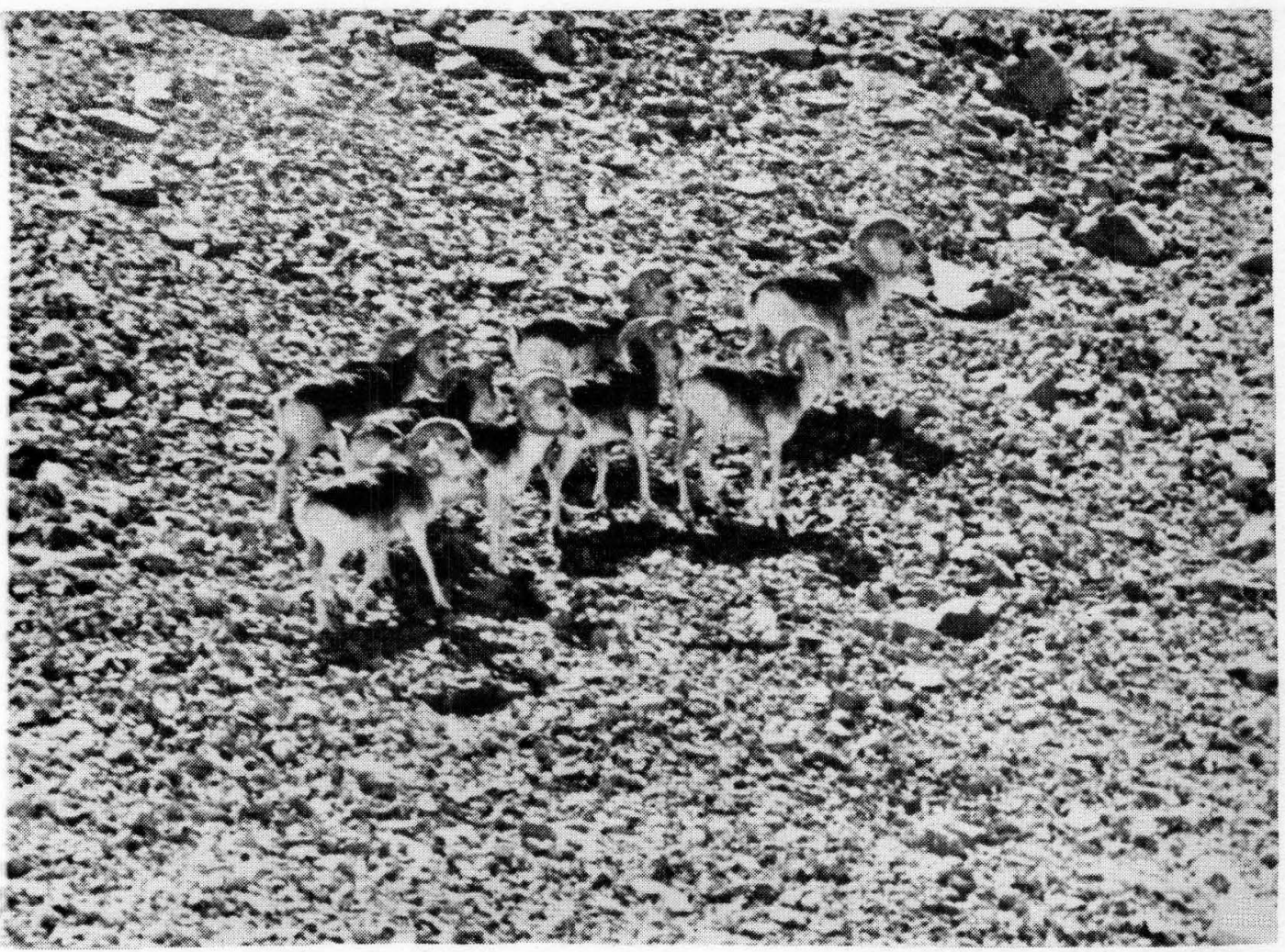

A band of eight Marco Polo sheep rams.

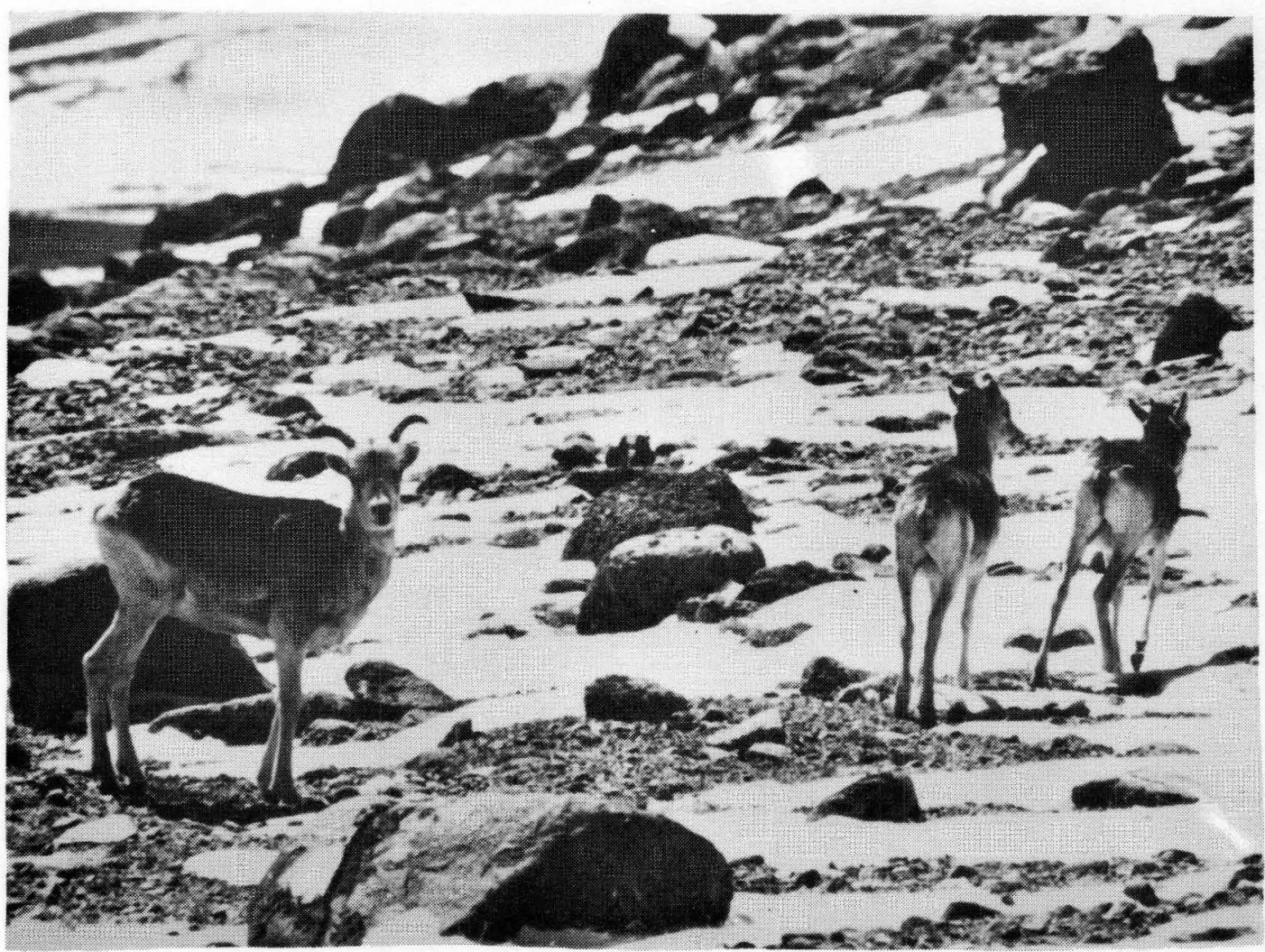

Marco Polo sheep female and twin lambs. 


\section{ABSTRACT}

This report is the second part of a three-part study of the Pamir Region. The information contained therein is largely a result of five seasons of field work in the Painirs. It contains a discussion of many aspects of the biology of this species of wild sheep including their distribution and movements, population characteristics, habitat utilization, activity patterns, social behavior which is focused exelusively on group structure and behavior during the rut and mortality. There is also a section on the influence of the local peoples on the sheep population; the tourist hunting programme is discussed as it relates to the three major horn morphotypes of the wild sheep. Additionally, there is a section on the present range conditions in the Big Pamir Reserve. 


\section{IINTRODUCTION}

This report is the second of a three-part investigation on the Afghar Pamir. Part 1, Ecological Reconnaissance, and Part 3, A Management Plan for the Big Pamir Reserve, have been published simultaneously as Project AFG/74/016 Field Documents numbers 5 and 7 . Collectively they represent a synthesis of five seasons of field work in the area between 1971 and 1976.

More than 700 years ago, one of the world's renowned explorers wrote of a spectacular species of wild sheep that inhabited mountains on the "Roof of the World". The now famous Marco Polo sheep (Ovis ammon poli), is still followed by the legendary aura of its namesake. Marco Polo sheep have inspired a complex of chronicles by those fortunate enough to have seen the animals in the course of the last 150 years (Wood, 1841; Dunmore, 1893; Bonvalot, 1889: Cumberland, 1895; Curzon, 1896; Clark, 1964; Kullmann, 1970; Petocz, 1971 and 1973; Skoglaind and Petocz, 1975, and others). These wild sheep occur throughout the Pamir of the USSR, China, Pakistan, and Afghanistan with such a wide distribution that it is surprising so little is known of their biology and world status.

In Afghanistan interest in these sheep began when the former king, Mohammad Zahir Shah, visited the Big Pamir more than 20 years ago and successfully hunted a trophy ram in an area that was reputed to contain the largest animals in the region. By royal prerogative, the king ordered that the wild sheep be protected in a single large valley which was afterwards used by the royalty and their guests as an exclusive hunting reserve. In 1968 permission was granted to an American safari outfitter to hunt wild sheep in this valley. Subsequently authorization was granted for a limited number of tourist sportsmen to hunt Marco Polo sheep in the reserve area through a programme operated by a newlym fomed. government agency, the Afghan Tourist Organization. Since then, both the hunting programme and reserve area have been expanded to the mutual benefit of the Government and local inhabitants of the area, at the same time protecting: a sizable portion of the wild sheep population. The programme represents the 
country's best effort to conserve while utilizing its wildlife resources and serves as an excellent model for future programmes directed towards other wild ungulate species in the country. It is the aim of this report to summarize the mejor characteristics of the Maroo Polo sheep population in Afghanistan that have so far been studied.

\section{STATENENT OF WORK ACCOMPLISHED}

The biology of the Marco Polo sheep of the Afghan Pamir has been previously discussed in special reports prepared for the Government of Afghanistan (Caughley, 1970; Petocz, 1971; Petocz, 1973A and 1973B; Skogland and Petocz, 1975; FAO, 1977). Additional technical reports are being prepared for publication (Petocz and Shank, in prep.; Shank and Petocz, in prep.; Petocz et al., in prep.). Investigations were carried out in both the Big and Small Pamir during all seasons excepting late winter and spring (February through May). Although it was not possible to collect comparative seasonal data for all aspects of wild sheep biology, an attempt is made here to synthesize the information accumulated most pertinent for the management of the species. See Figure I for location map of Walkhan Corridor and Pamir mountains 。

\section{METHODS}

All observations on the wild sheep were gathered with high-powered spotting soopes mounted on tripods. Every attempt was made to gain close access to animals under observation without causing disturbance. Scoping distances seldom exceeded one kilometer. Quantitative data were recorded on form sheets, while other observations were recorded as written notes or tapod and later transcribed. Field parties operated from a base camp or movable camps as the situation required, and usually daily trips were conducted 


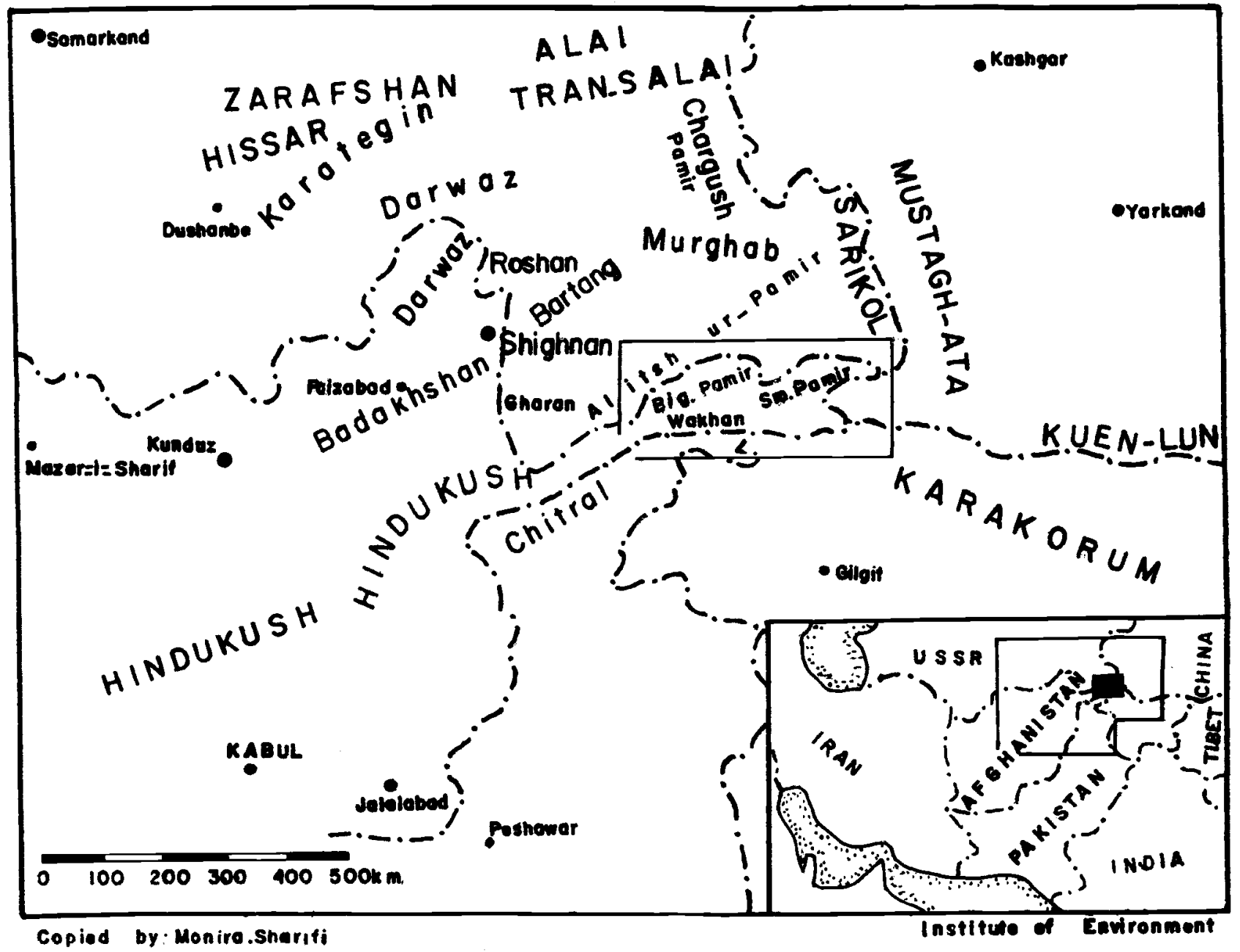

Figure 1. Location map of the Wakhan Corridor and Pamir Mountains (modified after Naumann and Neithammer, 1973). 
to the wild sheep range for the actual observations. Transportation and expeditioning was generally accomplished using horses and yaks rented from the local people. A total of noarly 13 months was spent in the Pamir rogion by the senior author between 1971 and 1976.

\section{DISTRIBUTION AID YOVERTITS}

Marco Polo sheep occur through a large section of the Wakhan Corridor which includes the Big and Small Pamir physiographic units as well as the Waghjir Valley. They are absent, however, in the section of the Hindu Kush mountains which lies south of the Darya Wakhan and runs up to the junction of the Washir and Aksu rivers. This section of mountainous terrain is instead occupied by Siberian ibex (Capra ibex sibericus) which are better adapted to the steep and more rugged terrain preferred by this species of the genus Capra. For similar reasons, ibex, not wild sheep, occupy most of the mountains lying south of the Aksu River on the frontier of Sinkiang, except for the easterimost valleys bordering China.

It is necessary to divide the wild sheep population into three parts on the basis of population characteristics and general movements (Figure 2 ). These are as follows:

1. The Big Pamir Segment: Seas onal concentrations occur in the western and eastern ends of the Big Pamir. Valleys in between are infrequently used, some not at all. In the west, wild sheep concentrations occur throughout most of the year. Major north-south movements in the western sector occur between Afehanistan and the USSR in the winter, but exclude females. Seasonal concentrations of animals in the eastern part occur from late June till October, with female groups being the first to arrive and last to depart. Major movements here are east-west between the Soviet Union and Afghanistan, with additional east-west movements occurring within Afghanistan at various times, particularly in September and October. 


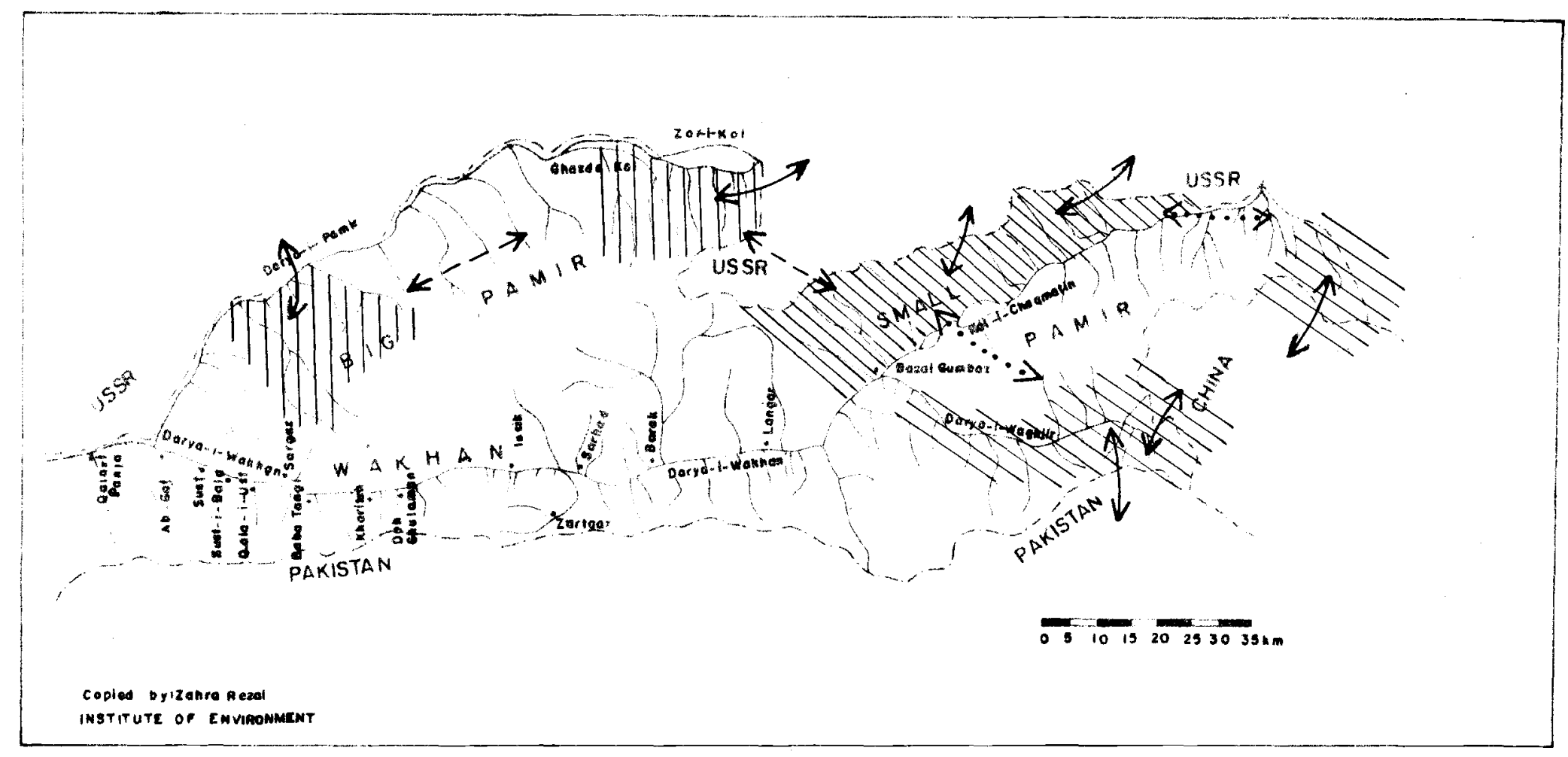

Figure 2. Distribution and movements of Marco Polo sheep in the Afghan Pamir. Legend: [IIIII - Big Pamir segment; - Small Pamir segment; and - Waghjir Valley segment. Arrows indicate directions of seasonal movements: —_ major; --.- sub-major; and ........ minor. 
2. The Small Pamir Segment: This segment consists of wild sheep which occupy the area north of the Aksu River, from Aqbeles Pass on the west to the Russian frontier on the east. Female-nursery groups utilize the area throughout the year with major concentrations occurring in June through December-January. Rams are found in the area mainly during the pre-nut and mut (October through mid-Jenuary); during the rest of the year only small home range groups of rams are found. Major seasonal movements are north-south between the Soviet Union and Afghanistan, but evidently little intermixing takes place between the above, the eastern and the Big Pamir segments. During their occupancy, wild sheep move back and forth across the border zone. In late autumn there is a general eastward shift so that most sheep are found in the few valleys near the easterin frontier with Russia.

3. The Waghjir Valley Segmeit: Little work has been accomplished on this sub-population, but reliable sources claim that there are large ooncentrations of rams during summer months in the Teger Mensu Valley, (the easternmost valley bordering on China and the USSP.). Here Marco Polo sheep move into Afghanistan from Pussia and China. Wild sheep can be found in the Waghjir Valley during August and September. Their movements in this area are between Afghainistan. China and Pakistan.

Movement and intermixing occur bctween theso three segmonts but the extent of this exchange has not been ostablished. However, investigations on the Big and Samll Pamir segments have yielded different and specific trends which can be closely oorrelated with the pastoral activities of the Valkhi and Kirghiz people in each area. These grazing practices have proved a controlling factor of population quality and have hal such an impact on the wild sheep population that a separate analys is of each geographic segment was neoessary to prevent a false characterization of the entire population (Petocz, 1973). 


\section{POPULATION CHARACTERISTICS}

All sheep observed were classified according to sex and age in the following manner: females $(F)$, lambs $(L)$, yearlings $(Y)$, and rams $(R)$. Rams were aged according to horn size (Petocz, 1973) and categorized into four classes: class I ( $2-3$ years old), class II ( $4-5$ years old), class III (6-7 years old) and class IV (8-9 years old). It should be pointed out that the system of classifying live rams is not perfect, as younger animals with larger homs would be placed into a higher age category, while older rams with shorter horns were sometimes placed among younger animals. However, in ram society, dominance is determined by horn size, not necessarily age, so the classification has a very high social significance. Brooming or horn attenuation presented no real handicap, as these rams oould be distinguished on the basis of massive or thin homs. Horns of deceased rams were exactly aged, except in the case of very old horns where annuli were no longer distinguishable. These were categorized by class division and included in the mortality data.

\subsection{Population Size:}

Census oounts were taken in the Big and Small Pamirs from 1971-1976, but in all cases must be considered partial. Seasonal variation in population size and differenoes in area covered each year are major factors which have made it impossible to monitor specific changes in animal numbers over the years. However, samples provided by the census clearly indicate trends in reproduction and population structure that are crucial in assessing the overall condition of the wild sheep population. An estimate of numbers of Marco Polo sheep in the Big and Small Pamirs was made by Petocz (1973) and can now be slightly revised on the basis of the sex ratios obtained during the rutting season in winter 1974-75. Table 1 summarizes the results of the most complete Pamir-wide census, taken duriing 1973. Only 27 animals 
(24 rams, 2 females and I lamb) were counted during the same year in Waghjir Valley which is not considered indicative of the total population in that area. Those data are therefore omitted.

Table 1: Results of the 1973 Maroo Polo sheep oensus in the Afghain Pamir.

\begin{tabular}{|c|c|c|c|}
\hline Location & Rams & Females & Lambs and \\
\hline
\end{tabular}

Big Pamir Segment

(West seotor)

(East sector)

Small Pamir Segment 162

Total
112

16

290
124

84

264

472
72

92

334

$498=1,260$ shecp

It was previously believed that the sex ratios calculated from the above figures, i.e., 61 and 62 rams per 100 females in the Big and Small Pamirs respectively, did not reflect the actual situation in either population segment and an adjusted $1: 1$ ratio was then used to estimate population size (Petocz, 1973). Evidence from other investigators indicated this to be the norm among other wild sheep populations (Murie, 1944; Cherniavski, 1962; Geist, 1971; Sohaller and Mirza, 1970). As the true sex ratio is probably best reflected when rams and females are found together during the pre-rut and rutting season, the ratio calculated during the late pre-rut and rutting season (7 December 1974 - January 1975) in the Small Pamir may in fact characterize the population. The maximum number of classified rams from each of the four age-classes observed on any single day was compared with the highest concentration of females $(N=64)$ on the Ortobjl-Jaman Sor rutting area. 
It was found that the earlier observations had been correct as can be seen in Table 2 below.

Table 2. Marimum numbers of rams observed on the Ortobil-Jaman Sor rutting area during winter 1974-1975.

$\begin{array}{ccccc}\text { Rar. classes } & \text { I } & \text { II } & \text { III } & \text { IV } \\ \text { Age Range } & 2-3 & 4-5 & 6-7 & 8-9 \\ N & 14 & 13 & 8 & 4\end{array}$

The oalculated sex ratio from the above data is 61 rams per 100 females, the same as that calculated from the 1973 census. No further adjustments on sex ratio were made. An estimate of the population size was made by doubling the total number of animals counted during 1973, which yielded more than 2500 wild sheep, excluding the Waghjir Valley segment. Doubling the actual count is considered necessary in this estinate to account for the probable numbers of animals missed in the census oount due to inaccessibility, areas missed and movements. Although subjective, the authors feel that the correction faotor is acceptible for indicating minimum numbers of Marco Polo sheep that utilize the Afghan Parnir.

5.2. Population Dynamics and Quality

The survivorship and mortality of rams in the Big and Small Pamir is presented in Table 3 for the years 1971-1975, following availaile data. It allows a valuable comparison to be made of rams between the two population segments of wild sheep. 
Table 3. Composition and mortality of Marco Polo rams in the Big Pamir Vildlife Reserve and the Small Pamir.

Location

Big Pamir Reserve

Big Pamir Reserve

Big Pamir Reserve

Average $\%$ found alive

$\%$ found dead

Small Pamir

Small Pamir

Small Pamir

Average $\%$ found alive

if found dead
Date

Horn classes

Age Range

1971

1972

1973

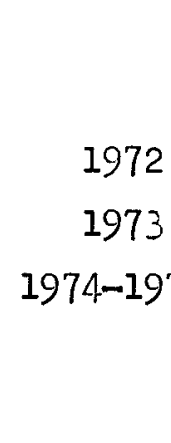

$(2$

$\begin{array}{lrlll}I & \text { II } & \text { III } & \text { IV } & \text { N } \\ 2-3 & 4-5 & 6-7 & 3-9 & \end{array}$

$20.6 \quad 29.4 \quad 26.5 \quad 23.5 \quad 34$

$\begin{array}{lllll}40.7 & 39.0 & 15.2 & 5.1 & 59\end{array}$

$40.4 \quad 29.4 \quad 20.2 \quad 10.0 \quad 109$

$\begin{array}{llll}33.9 & 32.6 & 20.6 & 12.9\end{array}$

$\begin{array}{lllll}8.3 & 34.3 & 36.7 & 20.7 \quad 96\end{array}$

$\begin{array}{lllll}58.3 & 16.7 & 25.0 & 0 & 36\end{array}$

$\begin{array}{llll}47.8 & 24.6 & 19.2 & 8.4 .203\end{array}$

$\begin{array}{lllll}38.7 & 30.7 & 16.1 & 6.5 & 62\end{array}$

$\begin{array}{llll}48.2 & 26.7 & 20.1 & 5.0\end{array}$

$\begin{array}{llll}2.9 & 31.8 & 41.6 & 23.7\end{array}$

Note: Mortality data. To avoid any duplication of data in the field, when single homs were found, only the right horn was aged and included in the final tabulation.

No attempt is made to analyze the year-to-year changes within each segment as census data oollected on an annual basis did not always coincide in season nor area oovered. This is olearly reflected in the number of rams actually classified. In 1972 for example, olass IV rams are oonspicuously absent in the data, as work was conducted mainly in female territoxy. On the other hand, in 1973 an attempt was made to cover both male and female ranges. In comparing the average percent composition of rams found in both areas, the following conclusions can be stated: 
1. The composition of the live ram segments are similar and are skewed towards animals in the younger age classes (class I and. II), particularly in the Small Pamir. The more numerous rams in class $I$ in the Small Pamir indicate a better survival among lambs and yearlings which is also reflected in the mortality figures. The youngest rams suffer little mortality (class I).

2. Rams seldom live beyond the age of nine years. Only one 10-year-old head was collected in the Big Pamir among the horns of deceased individuals; only eight 9-year-old individuals were found among horn material collected in the Big Pamir, and 16 in tho Soall Pamir. Compare Ovis ammon karelini in Geist (1971) which shows three 10-11-year-old rams found out of 61 specimens examined.

3. The mean age at death approximates six years for both Big and Small Pamir population segments which is the same as that of $\underline{0} . \underline{.}$. karelini. Mortality patterns are similar for both the Big and Small Pamirs.

The above conclusions indicate that there is a close agreement in populatinn structure among ram components of both segments. This oomposition, along with the short life expectancy of the rams, the rapid horn growth in the first two age classes (Petocz and Shank, in prepo), and a vigorous social behavior, fits Geist's (1271) definition of an expanding, healthy wild sheep population. Lacking supplementary data on females and young, there is no real justification for separating the two segments. Except for numbers of animals, the two grographical segments appear similar.

Females and nursery groups are more sedentary than males. They maintain fewer seasonal geographic ranges and thus remain longer in any specific location. Additionally, their movements on a specific geographic range are more confined than those of rams. Females and followers can usually be found grazing near areas 
where they were on previous days, while among rams this seldom happens except under duress of snow cover (Petocz, 1971). It is therefore reasonable to assume that trends reflected among female groups will be more areampecific and will better demonstrate local ecological conditions than will rams who may visit twice as many home ranges within a year's time. A close look into the situation in the Pamir lends credence to this important point as there exist some basic differences characterizing the female groups in both areas.

Unlike rams who possess visible morphological features that can be used to distinguish age classes and even to identify specific individuals from long observation distances, females are very monotypic. Although there are recognizable differences in body size between, for example, a yearling and a five-year-old, it is in fact sometimes difficult to distinguish between mature females and yearling rams, especially at long viewing distances. Compared. with rams, females are almost socially inert and outside the pre-mut and rut are tedious to observe. Nevertheless, it is largely the females who control. population size and quality, and a better understanding of them seems essential if a population is to be properly analyzed. In the absence of basic research on female mountain sheep behavior, the relationships between ewes and lambs provide the rnost telling evidence which indicate trends in this part of the population. These trends in the Big and Small Pamir female segments are examined separately below.

The relationships between females and lambs, and females and yearlings differed in the two geographic segments. Beginning with reproduction and survival of newborn and yearlings, it becomes evident from the figures in Table 4 that there are diverging trends in both areas. 
Table 4 Lamb production and survival in the Big Pamir Reserve and in the Small Pamir.

$\begin{array}{lccccc}\text { Location } & \text { Date } & \text { L/100f } & \text { Y/100F } & \text { iN(Groups) } & \text { 9survival } \\ \text { Big Pamir Reserve } & 1971 & 33 & 12 & 10 & \\ & 1972 & 52 & 17 & 24 & 52 \\ & 1973 & 51 & 22 & 15 & 42 \\ \text { Small Pamir Reserve } & 1976 & 71 & 4 & 27 & \\ & 1972 & 36 & 14 & 12 & \\ & 1973 & 74 & 30 & 50 & 33\end{array}$

From the sample in Table 4; it can be seen that there are considerable fluctuations in reproduction and survival of lambs from year to year. Differences in annual mortality among younf occur in most ungulate populations and should not be oonsidered unusual among Marco Polo sheep. There is a variety of factors whioh influences infant mortality suoh as nutrition base, snow cover and social stresses within the animal population, to mention a few. No attempt, however, is made here to analyze the annual fluctuations except in a general way.

In both the Big and Small Pamir populations there is a noticeable trend of increased production of lambs from a general low in 1971-1972 to more than double in 1975-1976. The low reproduction in the early 1970's is probably a response to the overall poor range conditions in the Pamir caused by the couitrywide drought which struck most of Afghanistan in 1970-1971. The general improvement of lamb production coincided with better range conditions after the drought, although reproduction in the Big Pamir did not show the dramatio increases it did in the Small Pamir. Nevertheless, oomparing the survival of lambs in both areas, the Small Pamir sheep show $41 \%$ more lambs survived from 1972 to 1973 than did in the Big Pamir (i.e., 83\% vs 42\%). Unfortunately, 
comparative data are not available for additional consecutive years. The lower yearling:female ratio in the Snall Pamir in 1974--1975 was before ascribed by Skorland and Petocz. (1975) to winter mortality, which also had an adverse impact on domestic stock of local Kirghiz people the same year. Although comparable data are not available for the same year for the Big Pamir sheep, the low survival of yearlings in 1976 cannot be attributed to olimatic conditions. The local Wakhi peopie familiar with oonditions in the Big Pamir indicated that conditions were normal in the Reserve during winter 1975. The low yearling:female atio $(4: 100)$ is attributed to poor winter range conditions in the territory of female sheep in the reserve arca caused by over-utilization of raingeland by domestic stock in the lower parts of the Big Pamir valleys. This is considered the major reason for differences observed between the two geographic population segments of Marco Polo sheep.

The discrepancies in reproduction and survival between the two subpopulations are further amplified by certain behavior patterns within the femalenursery bands. Table 5 summarizes data gathered at suckle times of lembs in both areas.

TAble 5. Results of suckling behavior of lambs in the Big and Small Pamir. Location Year Month Attempts Suckles Lamb Female $\bar{X}$ SD LD Big Pamir

(Trulibai V.) 1972 Sept-Oct 48

Big Pamir

1973 Aus-Sept 51

27

21

Bigg Pamir

(Thulibai V.)

Small Parnir

1976

Aus

28

23

27

Small Pamir

1973

Sept-Oct 43

1974-1975 Dec-Jan 23

9

48

$\begin{array}{llll}0 & 10.4 & 3.8 & 15.0\end{array}$

51

0 $8.1 \quad 4.7 \quad 15.3$ 28

0

$14.5 \quad 4.3 \quad 22.2$

( $\overline{\mathrm{X}}=$ mean, $S \mathrm{D}=$ standard deviation, $\mathrm{LD}=$ longest duration; all are cxpressed in seconds) 
No data are available for suckle times in the weelss immediately following parturition (early June). However, Geist (1971) presented suckling duration for bighorn (Ovis canadensis) and Stone's sheep lambs (Ovis dalli stonei) which showed an average of 56 seoonds for week-old lambs of a high-quality population (Stone's sheep), and only 18 seoonds for two-week-old bighorn lamis of a lowquality population. Shackleton (1973) found that the average sucicle times for a high- and low-quality population of bighom sheep were 38 and 19 seconds repectively in their second week of life. Referring to Table 5, in SeptemberOctober 1972, the mean suckling duration (10.4 seconds) for lambs in the Big Panir was less than that during the same months in 1973 for lambs in the Small Pamir (12.5 seconds). Moreover, the average suckle duration in the Small Pamir in 1973 exceeded that of the Big Pamir lambs by a factor of 20\%, even though the data for the Snall Pamir lambs were collected later in the season. Although the actual frequency of suckling for both groups is not lnown, a general pattern emerges based on the number of successful suckles per number of attenpts. In the Small Pamir in 1973 it was $68 \%(\mathrm{~N}=43)$, while in the Big Pamir the sizccess ratio was $56 \%(N=48)$ in 1972, and only 41\% (N=51) in 1973. Suclele bouts were always initiated by lanbs except in three instanoes, all of which occurred in the Small Pamir under similar circumstances. After a long resting period with both fenale and lamb Iying close to each other, the female rose and solicited her lamb to suckle by nuzzling it and possibly blcating. The resultant suckles were all above the averare in time: $15.8,14.6$, and 12.8 seconds.

Data collected during the pre-rut in the Small Pamir in 197/-1975 indicated that the females in this population segment were still lactatiilg, although by that time most lambs had charged over almost exrclusively to vegetation. Prolonged milk production into winter by females was also observed among high-quality bighorn sheep in Banff National Park, Canada (Petocz, pers. ols.).

The higher suckle durations among reserve lambs in August 1975 goes arainst the general trend of data recorded previously in the Big Pamir Reserve. As was recorded in Field Document No. 7, Part 3 of this report, these nursery grcups now enjoy the greatly improved range oonditions adjacent to the government hunting camp from parturition time to late october, approximately five months. 
However, local people have reported a high mortality among lambs . In winter 19761977 (Nematullah, 1977, pers. comm.). The data recorded in 1976 indicated a yearling:female ratio of $4: 100$ whioh is interpreted as a response to the overgrazed rangeland in the winter territory of females.

In general, the longer average suckling times for comparable years or seasons for the Small Pamir lambs indicate a higher level of nutrition for both the females and young in this population segment. Milk production is ultimately related to matemal nutrition (Brody, 1945, in Geist, 1971) and among lambs who were allowed longer suckling bouts, we should cbserve differences in their vigor as seen among other sheep populations (Geist, 1971; Shackleton, 1973). Supplementary observations of the lamb population in both areas support this view.

Lambs in the Big Pamir segment showed considerable variation in body size. Several months after parturition, many small lambs were present, some of which appeared to be nearly half the size of the larger lambs in the bands. This may have resulted from either late births, or insufficient nutrition, or both. Age and experience of the mother are important factors in producing viable lambs, yet size differences among lambs were less frequently observed among sheep in the Small Pamir. Since it has been shown that the age structure among the ram component of both populations is similar, a significant difference in age structure among females of either population segment would seem unlikely. Wo conclude then that most of the smaller lambs are the product of females of less than optimum health.

The vigor and general health of lambs is reflected in their behavior towards others in their age group as well as their relationship to their mothers. Big Pamir lambs were found to play and gambol less frequently than their counterparts in the Small Pamir. This was particularly evident in field notes from 1972 (Petocz, pers. obs.) when during 26 days of continuous observations of Big Pamir nursery groups in the Tulibai Valley, only four recognizable play periods were recorded. During eight days (about 49 hours) of similar observations in the Small Pamir, 14 distinct play periods were recorded. In the rare bouts of play recorded in the Big Pamir, smaller animals were unable to interact with 
the larsen. Since all behavior among lambs consists of contact patterins (i.e., butting, clashing, mounting) in addition to gamboling, the "subdominant" lambs would rapidly retreat from intended interactions and isolate themselves at their mothers' side. During grazing activity of ewes, these smaller lambs could be seen alternately foraging and resting near their dams with a periodicity of only a few minutes. In contract, Small Pamir lambs adopted the activity patterns of their dams, and therefore rested less frequently and foraged more. Play among these large-sized, vigorous individuals was frequent with usually one or two major bouts each day that lasted from roughly 12 minutes to as long as 47 minutes for one group observed. In addition to these regular play periods, out-breaks of gamboling and chasing about were commonly seen. Ewes occasionally raced about and played with the lambs, an action that was never observed in the Big Pamir groups.

In this regard it was somewhat surprising to see only two play bouts during 33 days of observations in winter 1974-1975 in the Small Pamir. It is possible that the presence of larger rams among the nursery groups suppressed these activities, or that survival in winter is more dependent on conservation of energy than on socialization with individuals of the same age group. Petocz (1973) has shown that there is a purposeful reduction in social behavior among bighom rams under duress of heavy snowfall. Although unconfirmed, it is likely that a reduotion in play even among high-quality populations is necessary for additional resting and grazing. Energy conservation is a basic theme of survival in winter (Geist, 1971; Petocz, 1973; Geist and Petocz, 1977).

Agonistic behavior was more predominant within nursery groups in the Big Pamir. Patterns employed were mainly butting, body butting, rushing and horis threat and were displayed in disputes over feeding and bedding sites, and to ward off suckling attempts by lambs. The antagonists were: $F / F, F / L, F / Y$ and $Y / L$. These patterns occurred also in the Small Pamir during winter and probably arose more from frustrations of the rut, with the irritating advances of smaller rams in particular causing social distress within nursery groups. 
Geist (1971) has pointed out that the lamb-mother bond is weak in mountain sheep and is probably only maintained by mutual necessity, that is, sucleling relieves milk pressure and sore teats for the mother while it satisfies the appetite of the lamb. The animals in the Small Pamir with their longer suckles, more vigorous play, larger size, and apparent closer attachment to their dams give an overall impression of being healthier animals. These are attributes characteristic of sheep populations in an expanding phase, as described in detail by Geist (1971).

\section{HABITAT UTILIZATION}

\subsection{Division of Habitats:}

Five habitat types utilized by wild sheep are described in FAO, 1978, Field Document No. 5. In documenting the habitat and food prefereinces of Marco Polo sheep, alpine heaths have been combined with rubble slope and scree habitats, as from most observation distances it was impossible to distinguish the interface between heaths and the high rubble slopes and ridge tops that were nearly devoid of vegetation. During the month of August, yet an additional habitat type was used by sheep which did not occur during any other part of the five-month analysis. Glaciers were frequented by both sexes during August 1972, where animals were seen at elevations above $5200 \mathrm{~m}$. It was pointed out earlier that glaciers were nearly absent on the sheep ranges of the Small Pamix but do form a part of the physiography of the Big Pamir valleys. During summer, however, the Small Pamir valleys contain snowfields at their highest extremities. Although data for the month of August were oollected solely in the Big Pamir, it is likely that a similar utilization pattern employing snowfields exists in the Small Pamir for reasons that will be made apparent. The habitats recognized in this analysis are sedge meadows, alpine steppes, rubble slopes incorporating alpine heaths and scree slopes, cliffs, and glaciers. For a discussion of the ecology of thesc habitats see FAO, 1978, Field Dociument No. 5. 


\subsection{Habitat Preferences of Maroo Polo Sheep}

Olassified counts of wild sheep were taken during the morning (0530-1200 hours), afternoon (1201-1700 hours) and evening (1700 hours). Data for a single day were combined and recorded in the following manner. The number of groups, rams, and females and followers oisserved in each habitat was noted; monthly totals were calculated for each habitat and. the percent utilization of each catagory of sheep was then plotted in the form of bar graphs represented in Figures 3, 4, and 5. From these data, a cumulative general preference index for each habitat type was calculated, and presented in Figure 6.

For the five-month period, the oumulative general preference of sheep for the available habitats followed this order: sedge meadows, alpine steppe, rubble slopes, glaciers, and cliffs. Females utilized sedge meadows and. alpine steppes about equaliy ( 41.6 and $39.2 \%$ respectively), while rams showed. a clear overall preference for sedge meadows (compare $45.7 \%$ for sedge meadows with $26.9 \%$ for alpine steppes), but used rubble areas (22.5\%) almost as frequently as the steppes. The cliff habitat was utilized so infrequently by all classes that it may be considered insignificant.

These patterns indicate that there may be more selectivity in choice of forage on the part of females and followers than there is by rams. Analysis of rumen samples collected from a ram and a lamb that were killed by wolves during winter in the Small Pamir tend to support this premise. The sample of the ram's rumen consisted primarily of sedges, while that of the lamb indicated a more varied diet typical of alpine steppes and rubble slopes (Skogland and Petocz, 1975; Petocz ot al., in prep.). Although sedges were highly preferred by both animals, the lamb also favored the fruits and flowers of Artemisia. Observations of bighom lambs and females in Banff National Park, Canada, confirm that this sex-age group tends to be more seleotive feeders than rams (Petocz, pers. obs.; Geist, 1968). A nutritional analysis of the vegetation is necessary before it can be determined which sex-age group is ingesting more protein in its forage seleotion. 


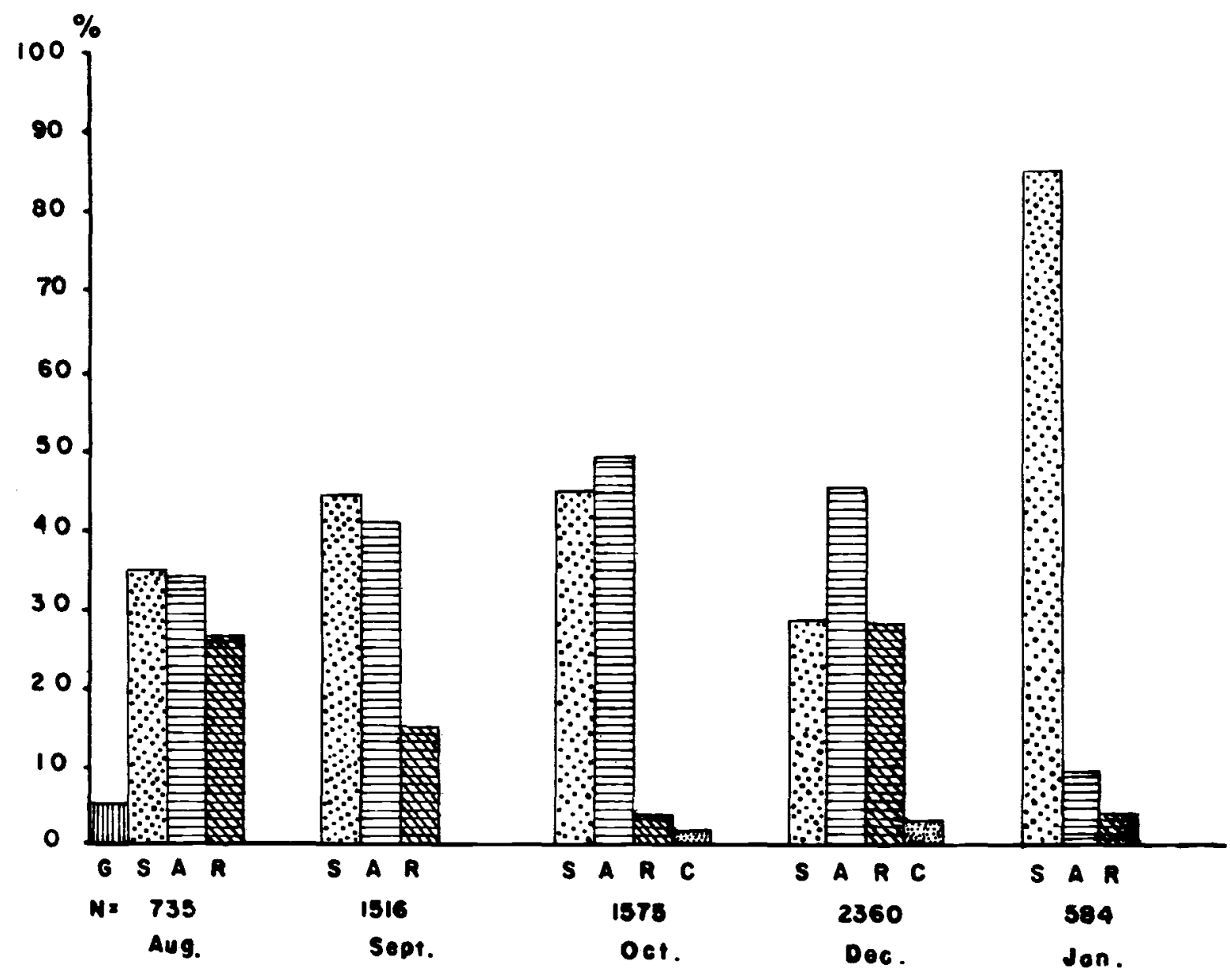

Figure 3. Habitat preference of Marco Polo sheep females and followers during the months of August, September, October, December and January, based on data collected from 1971 to 1976. (G-glacier, S-sedge meadow, A-alpine steppe, R-rubble slopes, scree and alpine heaths, C-cliffs.) 


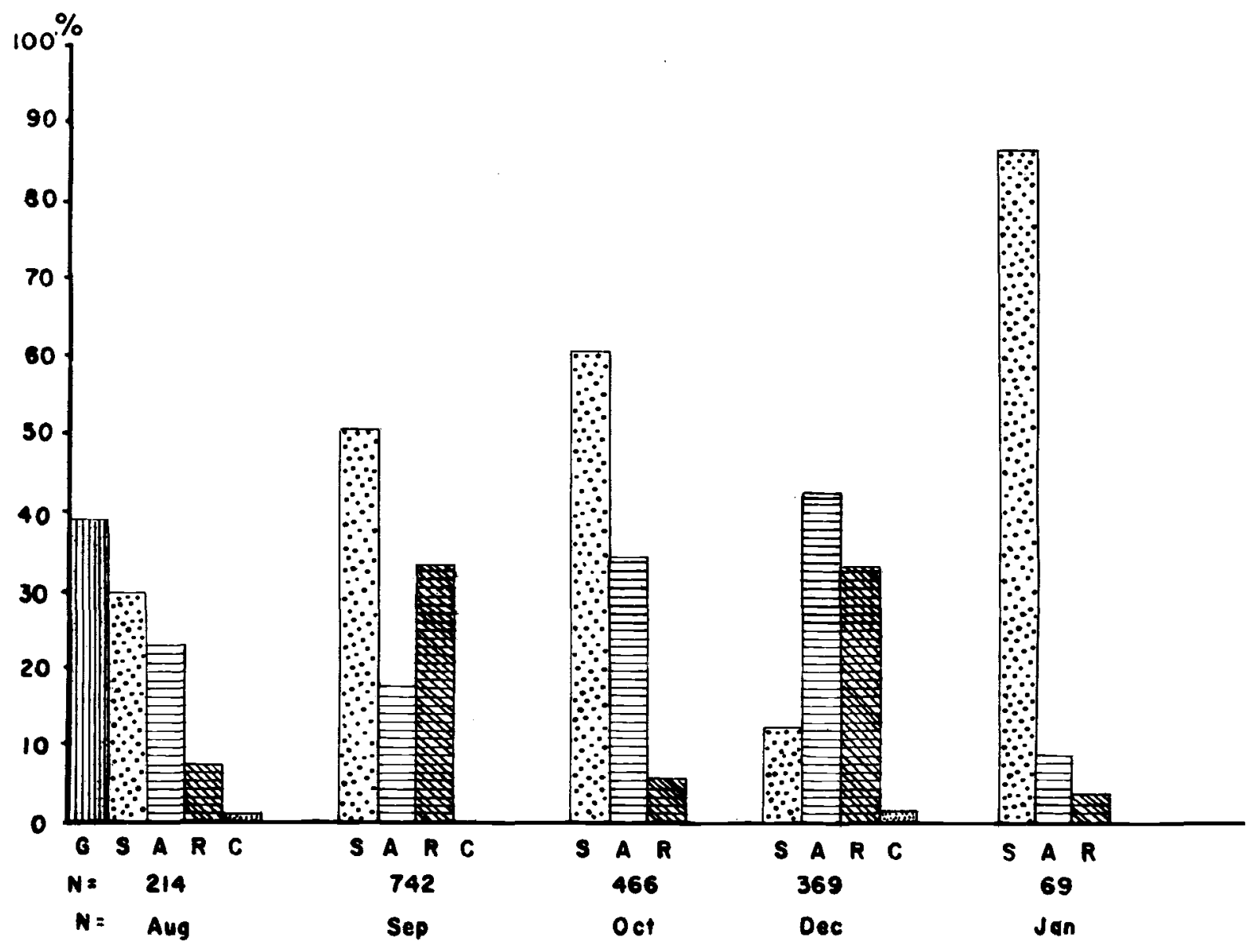

Figure 4. Habitat preference of Marco Polo sheep rams during the months of August, September, October, December and January, based on data collected from 1971 to 1976.(G-glacier, S-sedge meadow, A-alpine steppes, R-rubble slopes, scree and alpine heaths, C.cliffs.) 


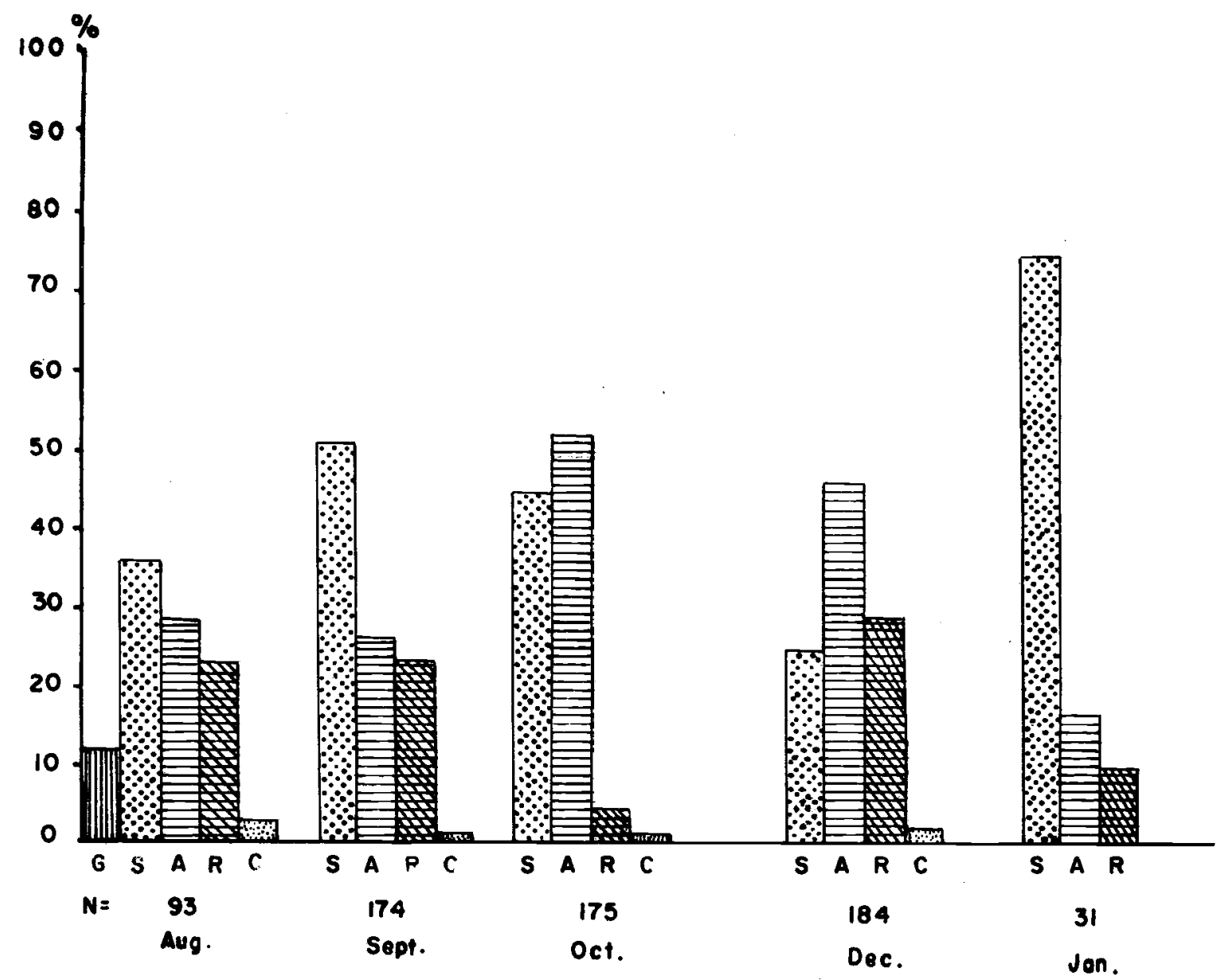

Figure 5. Habitat preference of Marco Polo sheep groups during the months of August, September, October. December, and January, based on data collected from 197/ to 1976. (G-glacier, S-sedge meadow, A-alpine steppe, R-rubble slopes, scree and alpine heaths, C-cliffs.) 
The preference for a particular habitat by sheep is also influenoed by availability of habitat space. In the Small Pamir, an index of availability was calculated by muning linear transects through habitat types and the percentage oover of the major species present was determined. For the sedges (Cyperaoeae: mainly Kobresia and Carex), the percent availability was calculated at $34.5 \%$, and only $18.6 \%$ for Artemisia, the seoond highest percent availability (Skogland and Petocz, 1975). These sedge meadows are even more abundant in the Big Pamir valley heads, jut transects have not yet been run to quantify this assertion. However, the abundance of sedge meadows decreases from the heads of Big Pamir valleys downwards towards the plain of the Pamir River where more xeric conditions predominate. Because rams locate in the valley heads through the summer and autumn while nursery groups remain further down valley, rams have even greater access to sedge meadows which dominate the landscape.

The very low utilization of cliff terrain was expeoted. In his North American studies, Geist (1971) has already pointed out that sheep are more adapted to the open terrain of vegetated mountain slopes (see also Geist and Petocz, 1977). The general avoidance of cliff or bedrock exposures by Marco Polo sheep indioates that their habitat requirements are further divorced from more mountainous terrain than those of North American sheop.

\subsection{Seasonal Variations in Habitat Utilization}

Late sumner, autumn and part of winter are reprosented in the data gathored over a five-month period from 1971 to 1976. Some ohanges or unique uses of certain habitats did occur over that period. In the month of August, sheep, and in particular rams, sought out high places on the glacial ice at the heads of Big Pamir valleys. Being one of the warmest months of the year, wild sheep attempt to escape the flies by moving to high elevations on cool and windy glaciers. Caribou (Rangifer tarancis) in Alaska move to high snow comices and glaciers for relief from the summer scourge of bleck flies, blow flies and. 


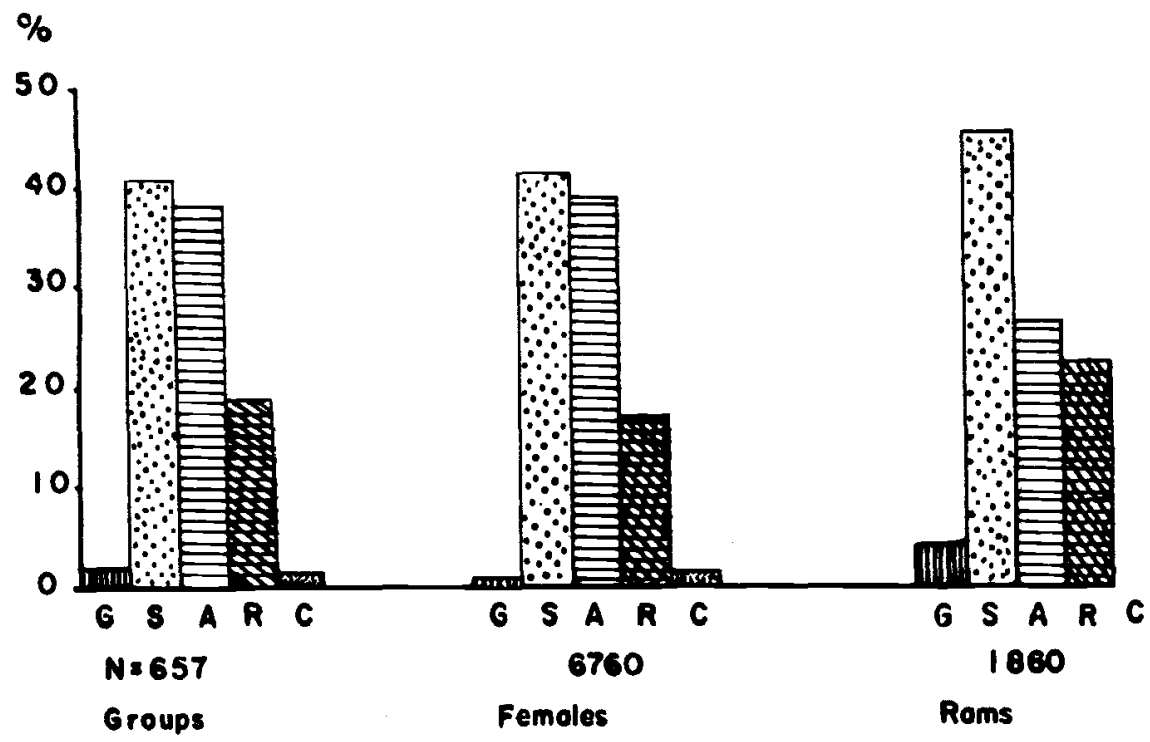

Figure 6. Cumulative general preference index for Pamir habitats by Marco Polo sheep over a five-month period (August, September. October. December, January): data were collected from 1971 to 1976. (G-glacier, S-sedge meadow, A-alpine steppe, $R$-rubble slopes, scree and alpine heaths, $C$ - cliffs.)

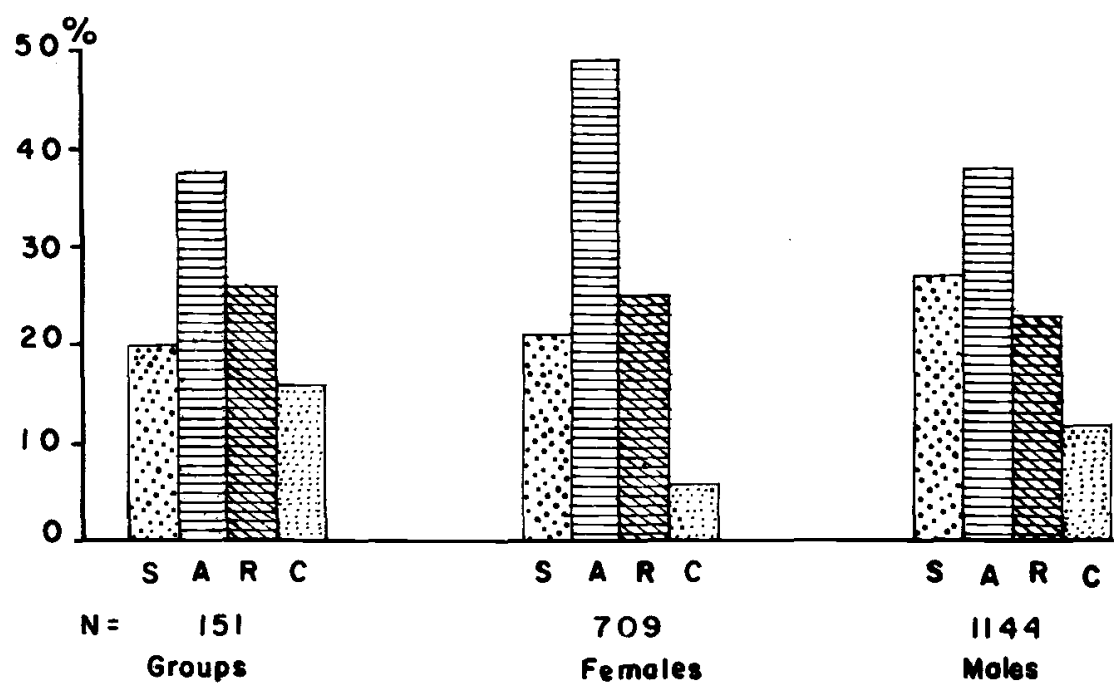

Figure 9. Cumulative general preference index for Pamir habitats by ibex over a five-month period (August, September, October, De cember, January); data were collected from 1971 to 1976. ( $S$-sedge meadow, A-alpine steppe, $R$-rubble slopes, scree and alpine heaths, $C$ - cliffs.) 
gnats (Petocz, pers. obs.). It is reasonable to surmise that for similar reasons, Maroo Polo sheep probably utilize glaciers and snowfields in June and July, along with ibex who spend a large part of the summer season at the foot of glacial moraines (Petocz, pers. obs。). It is not known to what extent Harco Polo sheep may use the Big Pamir ioe field as an avenue of dispersal on their moves to traditional home ranges. However, Geist (1968) has filmed bighorn sheep using hardened avalanohe snow as a means of access to nearby snow-free rangeland, and his observations lend credence to this possibility. Rams especially are usually found near glacial ice at the Big Pamir valley heads in August, September and October, which indicates a preferenoe for periglacial terrain with its lush sedge meadows (Figure 7). Likewise, in the Small Pamir, rams remain during these months in the highest parts of the mountain divide that separates Afghanistan and the USSR. They, in fact, only nove from the valley heads in the Big Pamir when they are forcibly ejected from the area by gradual snow accumulation when snow cover reaches unnegotiable proportions, probably as early as mid-December. This habitat behavior is probably rooted deep in the origins of this species of wild sheep which evolved during the advance and retreat of the ice cap in central Asia in the late Pleistocene.

Female groups showed a nearly equal preference for sedge meadows and alpine steppes during autumi (Figures 3 and 8 ). In this season, they remain largely separate from rams and locate on the more xeric slopes in the lower two-thirds of the Big Pamir valleys where the availability of sedge meadows is less. The intake of grasses and forbs may indicate a more elastic diet, and combined with selectivity of plants of higher protein oontent, could be considered an adaptation to grazing on poorer ranges. This is yet to be proven. However, the relationship of the female groups to domestic stock pastured in the Pamir region becomes clearer when viewed in terms of their respective habitat utilization patterns. The largest bulk of domestic stock in the Pamir is composed of sheep and goats which are pastured on alpine steppes in preferenoe to the sedre meadows or other available habitats. The increased 


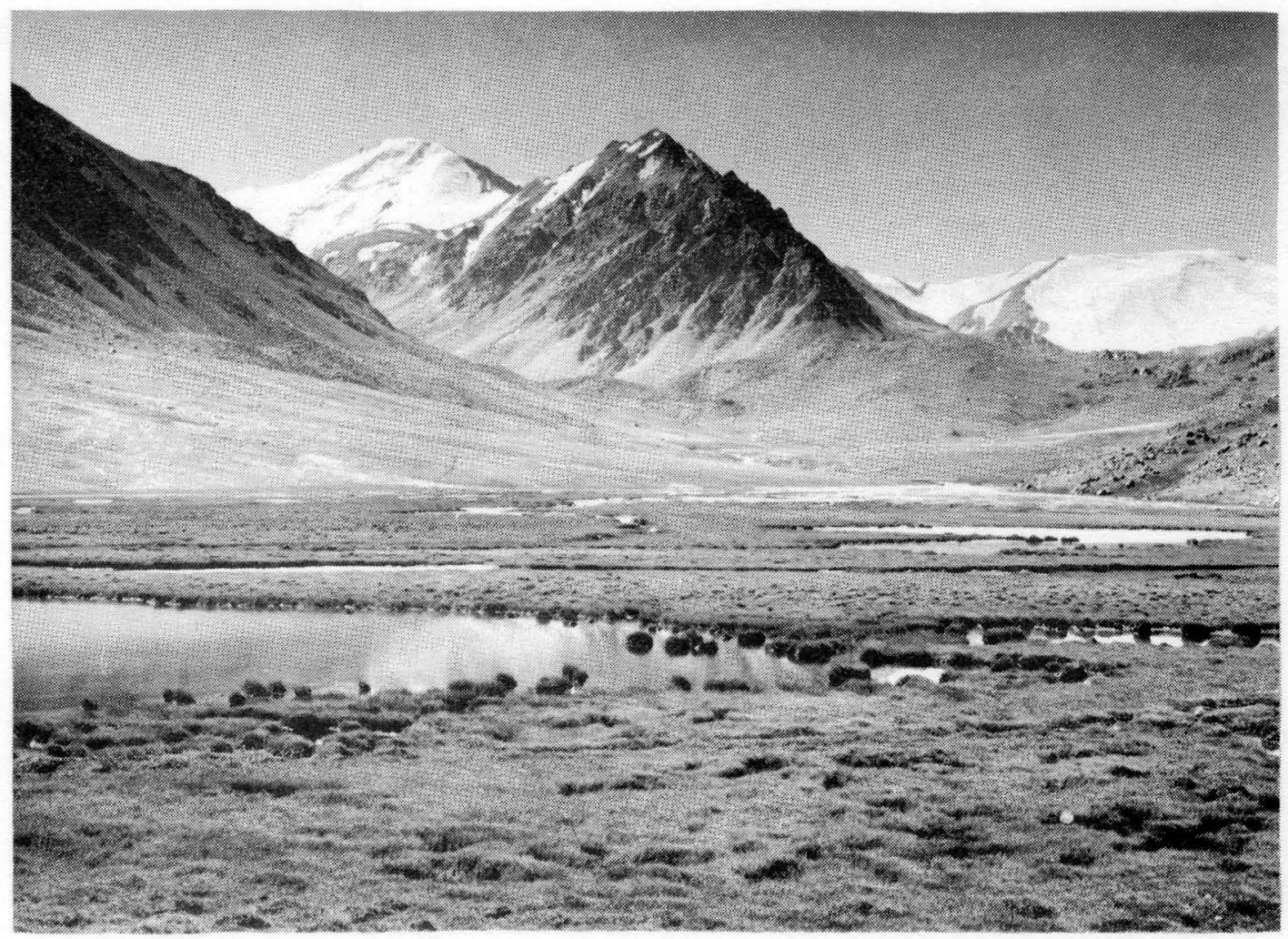

Figure 7. Sedge meadows in the periglacial habitat of Abakhan Valley in the Big Pamir Wildlife Reserve (elevation at the valley bottom $4590 \mathrm{~m}$ ). This habitat is favored by rams in late summer and autumn.

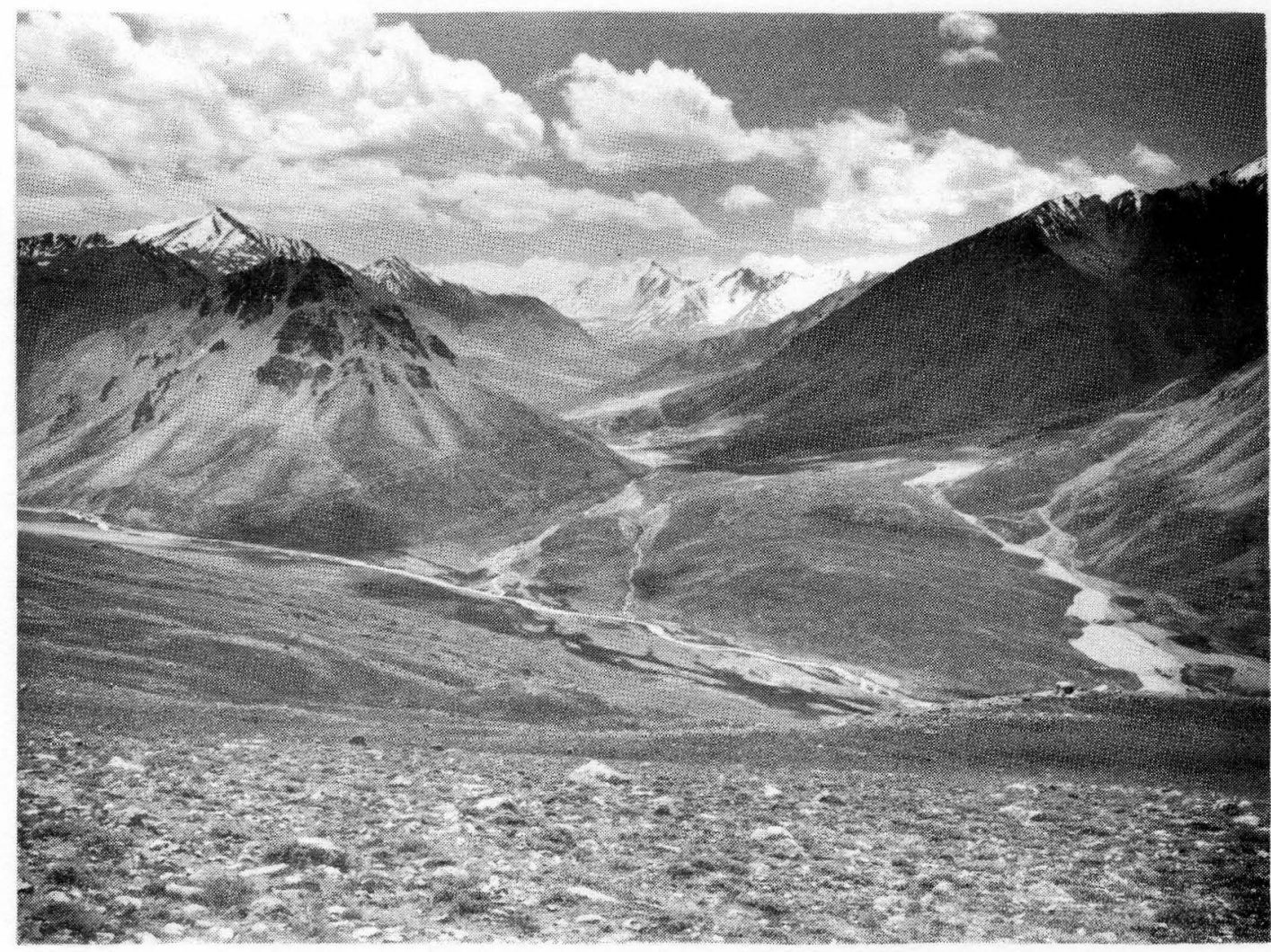

Figure 8. Preferred habitat of female Marco Polo sheep groups in autumn. The photograph shows the predominantly xeric alpine steppes, foreground, on the slopes of Tulibai Valley. Sedge meadows occur on the moist areas on the valley bottom and appear darker in the photograph (valley bottom elevation ca. $4070 \mathrm{~m}$ ). Sargaz Valley lies in the center. 
frequency of use of alpine steppes by females and followers through the autumn also indicates a more direct conflict with the domestics. Compared to sedge meadows and alpine steppes, less use was made of alpine heaths, and high rubble and scree areas. During autumn, particularly in Octower, female groups were found in these habitats more frequently than rams, while rams showed a preference for these habitats over alpine steppes in September (compare Figure 3 and 4). Among the females, the high rubble areas on ridge tops were utilized as escape terrain from the heat and flies, as substitutes for glaciers and snowfields that occur less frequently lower down in the valleys. Among the rams, there was an increased use of heaths and high rubble ridge tops coincident with the abandonenent of glacial terrain in September.

In December, the habitat perference of the animals clearly shifted to alpine steppes (Figure 5). The data gathered in the Ortobil and Jaman Sor areas of the Small Pamir during this month are interpreted as indicating a more diverse diet of the sheep at the beginning of winter. (Compare plant composition of the sedge meadows and alpine steppes in FAQ 1978, Field Document No. 5, Table 1.) more concentrated grazing on alpine steppes before the winter snowfall, and the increased utilization of frozen alpine heaths and the sparse vegetation on wind-swept ridge tops indicate a selectivity of vegetation, confirmed by the rumen contents of the lamb found in this area (see page 17). As snow cover increased, the animals were compelled to excavate feeding craters to gain access to vegetation. Since bare ground, gravel and rock form more than 50\% of the alpine steppe habitat in the Small Pamir (Skogland and Petocz, 1975), it is suspected that all the sheep prefer to forage on sedge meadows, as success of reaching vegetation cover on these snow-covered habitats is about $30 \%$ higher in this habitat than on the steppes (Skogland and Petocz, 1975, 
Table 11). Here again, the theme of energy conservation directed towarăs body maintenance comes into focus. With increased snow cover, Marco Polo sheep concentrate on the sedge meadows, which on the average contain only $15 \%$ berron ground. While they continue to uso the alpine steppes, foraging is directed more towards plant species which are exposed or protrude from the snow. Snow-pawing of feeding craters are noticeably concentrated around protruding plants (usually Artemisia scrui) in alpine steppes, while it appears random among animals grazing on the sedge meadows.

For the month of January, data are only available for the first week. However, at that time there occurs a dranatic change in preference for sedge meadow habitat by wild sheep for reasons previously mentioned. Although no definite conclusions can be drawn from the small amount of data available, we suggest that during January and through most of winter, Marco Polo sheep select herbs of highest nutritional quality from the nore exposed rubble slopes and heaths, but obtain their greatest forage bulk from excavated feeding craters in the more extensive sedge meadovs.

\subsection{Comparison of Habitat Preferences of Wild Sheep and Ibex}

The habitat preferences of Marco Polo sheep and Siberian ibez were found to differ in the Parnir (oompare Figures 6 and 9). The alpine steppes were the most preferred habitat of iber $(41.2 \%)$, followed by mbble slopes and scree (24.6\%), sedge meadows (22.8\%) and cliff terrain (11.4\%). But, although a difference in preferences is indicated, there is a signiricant amount of overlap in habitat use in the Pariir between these two ungulate populations. For example, female Marco Polo sheep showed a preference for alpine steppe habitat that was computed at $39.2 \%$, while the preference for mbble areas by Marco Polo sheep was oomputed at $22.5 \%$ Both of these figures compare closely with that of the general habitat preference of ibex. A more complete comparison of the habitat behavior of Marco Polo sheep and 
Siberiain ibex will be published later as a separate paper. It will suffice to point out that ibex exploit most heavily the habitat type whioh is utilized most extensively by domestic sheep and goats. Data on numbers of ibex in the Pamir do not lend themselves to an accurate estimate of their population size. However, it can be stated with some certainty that the iber along with Maroo Polo sheep females and followers compete directly with domestic sheep and goats.

\subsection{Spatial Distribution of Wild Sheep}

The overall physiography differs in the Big and Small Pamir mountains, as mentioned. These differenoes have had an impact on the general distribution of ram and female groups oil their seasonal ranges. Specifically, the valleys of the Big Pamir are on the average approximatel 20 to $25 \mathrm{kms}$ long and have glaciers emanating from an ice cap which culminate at the heads of these valleys. The mountain valleys comprising the Ilarco Polo sheep range along the Soviet border in the Snall Pamir average only ca. $10 \mathrm{kms}$ in length ard have no glaciers except at their western ond. Most Marco Polo sheep in the Small Pamir utilize rangeland to the east. It is a well-established fact that in wild sheep society, the sexes remain separate throughout most of the year excepting during the later part of the pre-rut and rutting season, at which time the two groups mix freely (Geist, 1971; Shackleton, 1973; Cherniavski, 1962; Egorov, 1965; Petocz, 1971 and 1973 ; and others). The segregation of the two components of the population also has a special significanoe in the overall employment of rangelaind. In the longer valleys of the Big Pamir, the Maroo Polo sheep are distributed bimodally throughout much of the year, with rams ocoupying preferred areas at the valley heads, and females and followers remaining in the lower valley reaches. With the advent of the rutting season and winter, the large males move down valley to breed, but again slowly separate from the fomales after the last signs of estrus. Movement back towards the valley heads occurs in 
pace with melting snow (Nematullah, 1972, pers. comm.). In contrast, in the shorter valleys and less rugsed mountains of the Small Pamir, male and female bands segregate themse?ves by occupying different valleys. These divisions are important in analyzing the relationship of wild sheep and demestic stock, which in combination with other elements, form the basis for the differences between the Big and Small Pamir sheep population.

\section{ACTTVITY PATTERINS}

Studies on activity patterns of mountain ungulates are generally lacking. Geist (1971) discussed winter activity patterns for Stone's sheep and mountain goats (Oreamnos americanus), and Skogland (1974) the activity of caribou. The analysis of ungulate activity behavior is a complcx subject and one which is effected by many different factors. Petocz (1970 and 1973) has pointed out how snow cover moulds the activity patterns of bighorn sheep in winter. During more clement seasons, however, there are other factors which iniluence the activity patterns of a group of mountain sheep, including availability of . forage, composition, group size, social oycle, habitat, insects and predators, to mention a few. It is beyond the scope of this discussion to consider all these points. Only the grazing activity patterns for a four-month period represeinted in Figure 10 are discussed below.

\subsection{Methods}

Field data were reoorded on form sheets. A group of aninals was observed for as long a period as was possible, and at the end of each riveminute interval the number of sheep was noted in the categories of feeding standing, moving, resting, interacting, etc. At the end of each half hour of observation, the recorded data were added and the percentage figures computed for each category. At times it was possible to observe a group for an eatire 


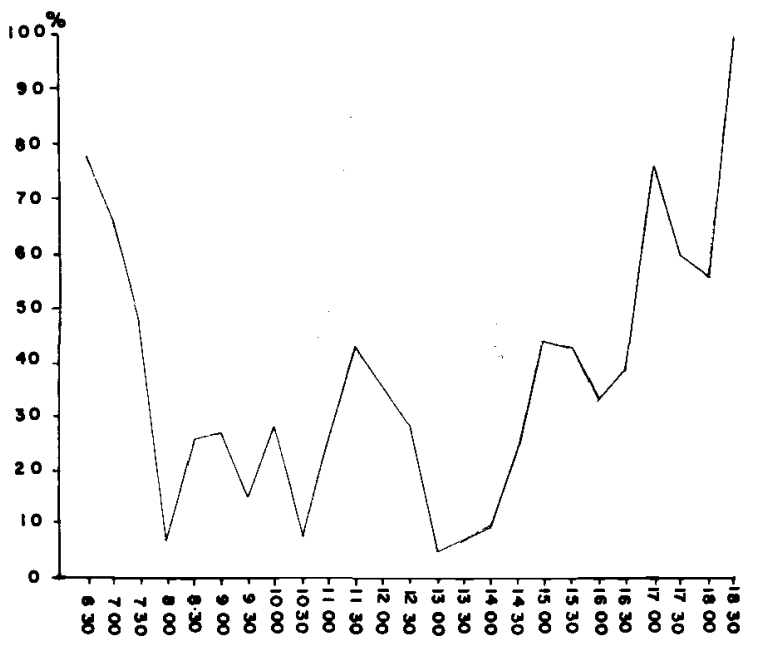

a) September 1971-1972: 13 ram groups; SD range $0-52$.

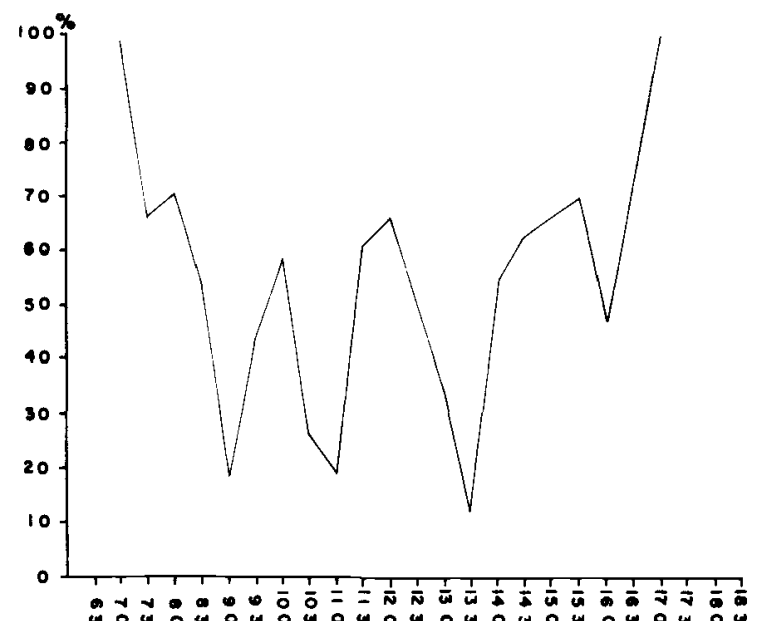

过8

c) October 1972: I ram group and 12 female groups; SD range $0-48$.

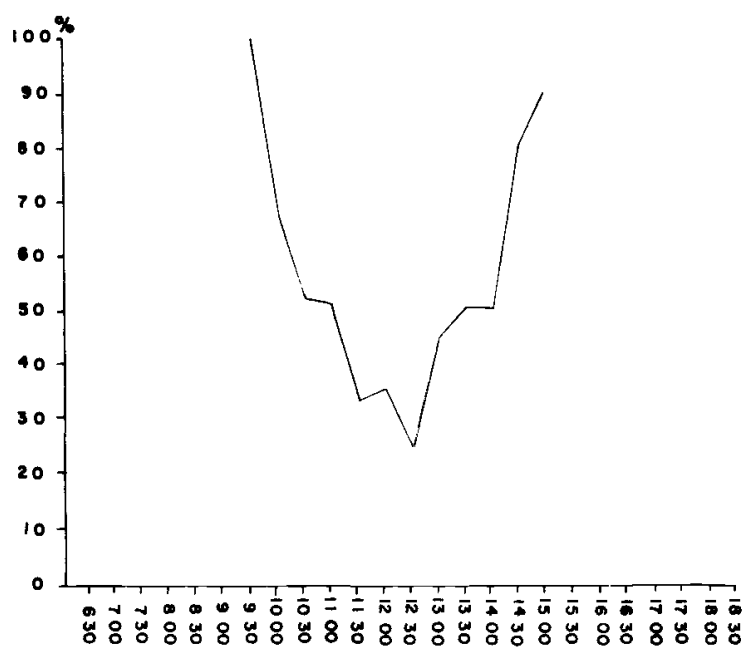

e) January 1975: 3 mixed groups; SD range 0.44.

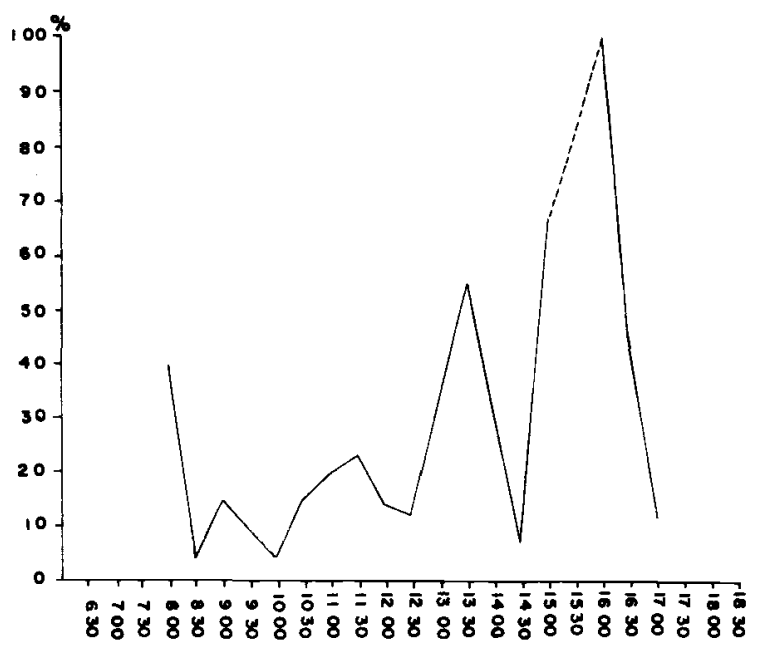

b) September 1971-1972: 5 female groups; SD range $0-34$.

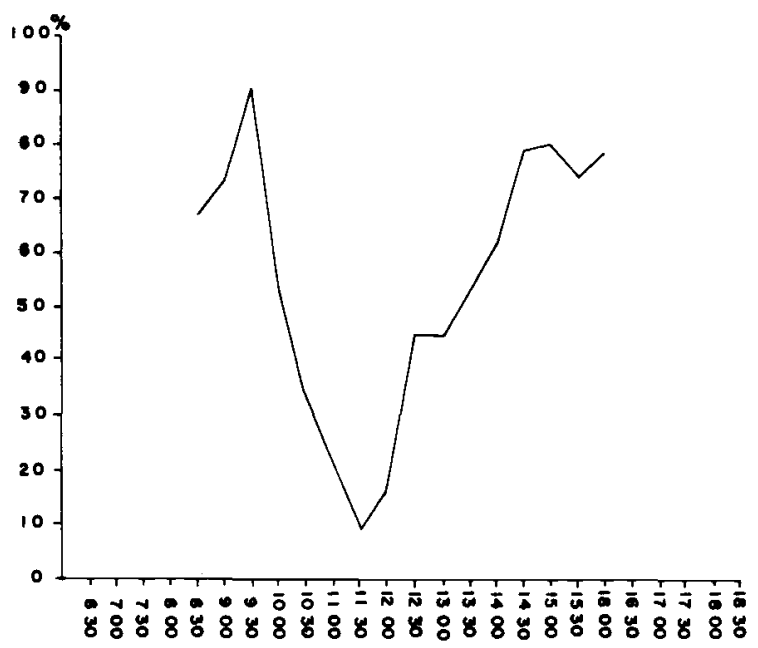

d) December 1974: 2 ram groups; 5 female groups and 3 mixed groups; SD range 0 48.

Figure 10. Grazing activity patterns of Marco Polo sheep for the months of September, October, December and January (Graph coordinates:

$\%$ animals actively grazing; time in half-hour intervals. SD - standard deviation.) 
day; at others only for a few hours. All these data were compiled to construct the mean monthly grazing activity patterns illustrated in Figure 10.

7.2. Results:

The interpretation of the monthly grazing activity patterins is given below. However, for the month of September, the data collected in 1971 and 1972 were combined and compiled separately for male and female groups. On all of the graphs in Figure 10 a single point represents the average time spent grazing relative to the other five categories of activity reoorded. The large standard deviations noted under Figure 10 account for the influences mentioned previously.

a) September 1971 and 1972-Ram Groups: Figure 10a shows the average activity pattern for 13 ram groups, from observations in $\Lambda$ bakhan Valley in the Big Pamir. The average group size was six animals. During the recording time, snow cover was non-existent or so slight or temporary that it was not considered significant. In general, there was a lack of synchrozeity in grazing activity through most of the day. Groups were more than $75 \%$ active during early morning and evening hours. The burst of social activity at the beginring and end of the day was the impetus behind these two most highly coordinated grazing bouts. The stratification of age groups within ram bands disrupted any unified grazing activity throughout the rest of the day. It was common to observe animals of one ram class resting while the other olass or classes grazed 10 meters or more distant fron their companions. Aotivity patterns among rams within a single group appeared more diverse if the animals present were separated by one ago class (i.e,olass I and olass III rams).

b) September 1971 and 1972-Female Groups: The graph in Figure 10b illustrates the average grazing activity of five nursery groups and is based on data gathered in Tulibai Valley in the Big Pamir. The mean 
group size was 20 animals. Although data were not available during the early moming hours, the activity trend is sinilar to that of the rams. The synchroneity of grazing activity broke down in these larger groups as animals became more dispersed and lost sight of each other. The more cohesive a group, the more uniform was its activity. Although this factor could not be measured quantitatively, group cohesion deteriorated after the initial grazing period of the morning. It was noticed that some animals even broke off from a larger body to form sraller groups of their own. With nightfall, females would nost frequently return to traditional bedding areas that were visable as small platforms soulptured on the mountainside. The resting period would then usually be initiated by a fenale with a lamb, after at times considerable confort movenents; this pattern was then adopted rather quicisly by the rest of the group.

c) October 1972: The graph in Figure 10c represents the mean grazing activity of 12 nursery groups and one ran group. The avcrage group sizo was 14 aninals. Date woro collocted in Tulibai Valley in the Big Pamir Wildlife Reserve. There was light snowfall on several days during this month but snow cover did not persist and did not visibly effect the activity of the animals. In general, the grazing activity of the sheep which included at least $60 \%$ of the animals present occurred during four pealss. As in September, the nost noticeable synchroneity occurred during the early morning and evening hours. Among bighorn sheep, the grazing activity during summer months was found to be periodic but nore synchronized (Petocz, pers. obs). The patterns reflected in the September and October graphs may then indicate a deterioration of this more synchronized grazing activity characteristic of months when vegetation is in its best condition. This, however, remains to be verified.

d) December 1974: The graph in Figure lod represents the mean grazing activity of ten groups of sheep: five nursery, two wale, and three mixed groups. The average group size was 13 animali. These data were gathered 
on the rutting range on the Ortobil Pass area of the Small Pamir. The graph shows two major peaks of synchronized activity, mid-morning and late afternoon. Snow cover in the study area existed in all habitats with an average depth of feeding craters from 5 to $15 \mathrm{~cm}$ (Skogland and Petocz, 1975). The morning activity peak probably coincided with a softening of the snow crust as was the case for other North American sheep (Petocz, 1973), although this could not be accurately measured in the Pamir study area. Geist (1971) presented activity graphs for the mountain goat and female Stone's sheep in December which showed an inverse correlation with the grazing patterns of Marco Polo sheep. He interpreted the single major activity peak which occurred between 1000 and 1630 hours as a response to temperature, reflecting the animals' preference for warmth while the extended feeding period appeared indicative of the difficulties of sheep in obtaining sufficient forage in short time. Although low temperatures were common in moming and late afternoon, there is no correlation of the activity of Marco Polo sheep with the highest daily temperatures; on the contrary, the opposite appears true. Rather, the grazing activity in this area coincided largely with the activities of the local Kirghiz people, as pointed out by Skogland and Petocz (1975). The disturbance factor originating with humans or their domestic stock was always very high $(66.6 \%$ with $\mathrm{i}=27)$ which altered the pattern that may have been more characteristic of winter and Geist's interpretation.

e) January 1975: The activity patterns averaged in the graph in Figure 10e were the result of observations on three mixed groups with a mean sige of 13 animals. As in December, the data were taken on the rutting range on the Ortobil Pass. The pattern is essentially identical to that of December. The activity peaks also corresponded to the most socially active time for rutting rams. The oinset of the rut, however, appears to have had little influence on the overall activity of the sheep from the previous month. 
8. SELECTED COMMENTS ON THE SOCIAI BEHAVIOR OF MARCO POLO SEEEP

In the oourse of biological investigations of the Marco Polo sheep in the Pamir, considerable data have been collected on the social behavior of these ungulates. However, comments are restricted to aspects which are more management oriented and will include some observations peouliar to the Naroo Polo sheep that will be of general interest to the students of wild ungulates.

\subsection{Resultś}

Maroo Polo sheep have basically the ame action patterns that were described for North American sheep by Geist (1971), Petocz (1973) and Shackleton (1973). Although there are some qualitative differences eleborated in seotion 7.2.2., the divergence in social behavior between species of the genus Ovis are mainly quantitative. Also, differences between the Big and Small Pamir Maroo Polo sheep populations were more a matter of intensity, or frequency of interactions. These were interpreted as aspocts of population. quality.

\subsubsection{Group Structure}

The bar graphs in Figure 11 show the distribution of group sizes over a five-month period. In late summer (August) and early autumn (September), it was rare to see groups oomposed of more than 20 animals. Most groups tended. to be snall (less than five animals) and were either ram or female bands. Mixed groups formed only $7.7 \%$ of those observed in August and $13 \%$ in September. Groups became progressively larger through the autumn into winter as the percentage of mixed groups increased (compare Figure 11 and 12). In October, mixed groups comprised 24\% of those ouserved, while in December they formed. $34.1 \%$ and finally in early January, mixed groups were oissorved almost exolusively (91.7\%) (Figure 12)。 


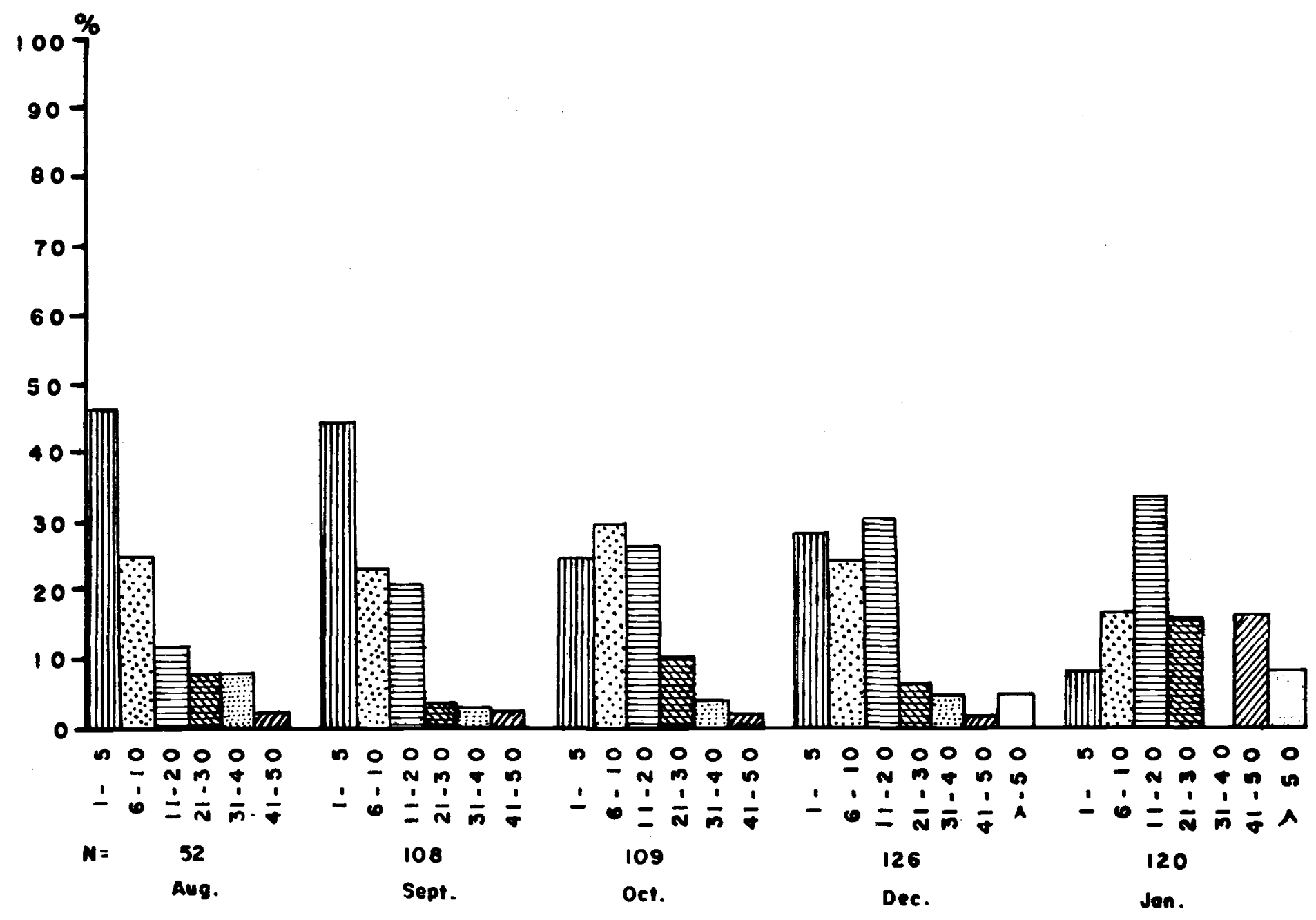

Figure 11. Percent distribution of group sizes of Marco Polo sheep from late summer through the rut ( $\mathrm{N}$-number of groups). 


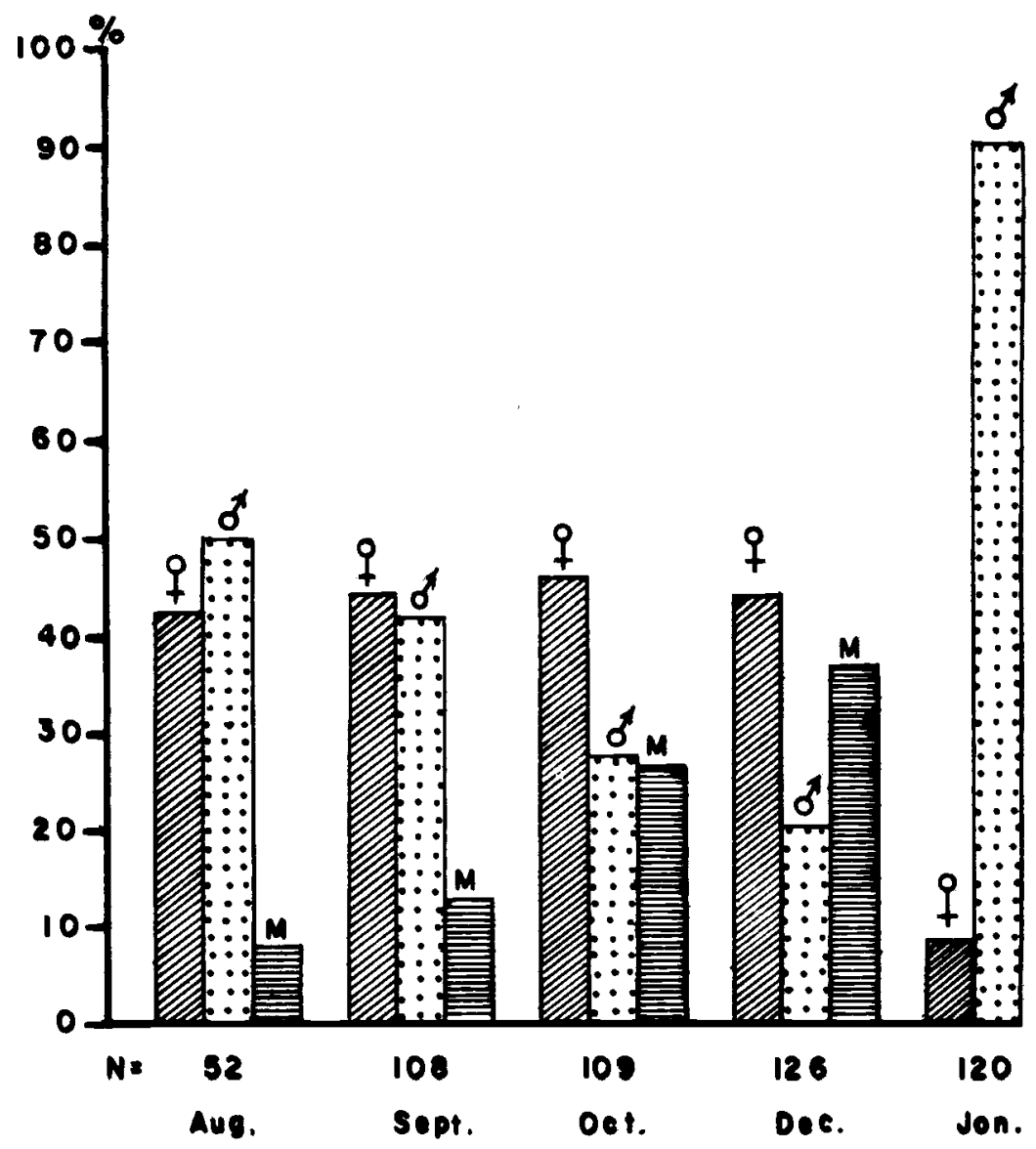

Figure 12. Percent composition of Marco Polo sheep groups from late summer through the rut ( $N$-number of groups). 
The more frequent sightings of larger groups corresponded to the convergence of Marco Polo sheep on their rutting rainges. Groups oomposed only of females and young which formed a remarkably oonstant peroentage of all groups observed from auturn through December were not seen during the rut. The progressive and constant decline in sightings of all ram groups can be correlated with the increase in mixed groups from late sumer till the rut and is indicative of the gradual attachment of rans to females by first younger, then mature rams. In summary, it can be stated that during the seasons ouserved, Marco Polo sheep form smaller groups, that are largely composed of individuals of the same sex. This social preference breaks down with increased group size and the advent of the rutting season. As was pointed out previously (Skogland and Petocz, 1975), a common response to predation among mammals as well as birds is increased group size. Rutting arimals, particularly the larger rams, are probably more susceptible to wolf predation during and after the rut as compared with other times of the year. The energy drain of courtship and herding behavior with considerably less time spent grazing during this period would increase their risk of succumbing. The formation of these larger groups in winter is thus believed not only to be an adaptation to divert predation, but a specific response to conserve energy by limiting mobility of rutting rams to a more confined area.

\subsubsection{Notes on the Rutting Behavior of Marco Polo sheep}

A disoussion of the rutting behavior of Marco Polo sheep was presented earlier by Skogland and Petocz (1975). The salient points of this discussion are summarized here because of their importance to the management of the species. Unlike most other northern ungrulates who rut from September to roughly midDecomber when they are in their prime before winter, the Marco Polo sheep rut during the last part of December and early January for a period of about two weeks. During 1974-1976 the first female in estrus was observed on 24 December and the last on 6 Jenuary 1975. During this time, the sheep rut on a subsistence 
diet where they can little afford to exert themselves beyond a certain threshold. There was a noticeable cyclicity of sexual and aggressive behavior where nearly every second day seemed to be a rest day with little or no social behavior activity. This type of behavior could be explained as an adaptation agsingt pred-tion (Estes, 1966), or it could be a specific adaptation to cope with the limited nutritional resources of the habitat. The timing of the rutting season does, however, have an adaptive significance, keyed to a more favorable period of lambing for the sheep which occurs during the Pamir spring in June.

There was a noticeable tendency towards herding of females on the part of class III and.class IV rams. The more dominant males would chase and circle females, using the low stretch, generally with the nose slightly raised, sometimes twisting the horns from left to right, and even directing sharp butts to the body trunk of females in an attempt to cut them off from the main herd and in particular other rams in the region. Skogland (1974) recorded this as a Poaturo of reproductive unit formation among wild reindeer in Norway. Herding is also a well-documented feature of the North American elk (Cervus canadensis) during the rut (Struhsaker 1967; Knight, 1970; and others), but unlike elk, mountain sheep do not defend territories. Shackleton (1973 and pers. com。) recorded herding behavior among bighorn sheep in Canada, which, however, seems more subtle than that performed by the Marco Polo rams. This type of herding behavior displayed by Marco Polo sheep is probably an adaptation to restrict the actual breeding potential of less mature rams in the vicinity.

The two oldest classes of rams interacted most with females and copulated successfully more times than did class I and II rams, although class IV rams interacted more with females when the number of sexual interactions were weighted according to the proportion of rams present. However, all the stimulus-eliciting and estrous synchronizing behavioral patterns performed by class IV rams were present and used by class III rams. This particular observation is important, since it can be stated that elimination of a segment of the oldest male class (i.e., the trophy rams) by the tourist hunting programme before the rut will not have any ill effects on the population socially or 
dynamically. This information is of particular importance for the hunting programe in the Big Pamir Wildlife Reserve, as current estimates place the olass IV animals in that population at a level of about $12 \%$ of the current ram population, or about 24 individuals. The current harvest of 12 animals does not harm the sheep population, as it has been shown by Skogland and Petocz (1975) that a reduction of rams in this age groups is not detrimental to the brceiting population.

\section{HORU MORPHOLOGY OF MARCO POLO SHEMP RAMS}

It became apparent throughout the study that there were some major differences in the horn morphology of Marco Polo rams that had not before been recognized. Three different morphotypes have so far been observed, which are illustrated in Figure 13 through 15. They are important not only from a biological standpoint but also because of their bearing on overall trophy size in the ram population which is a direct concern of the government's hunting programme in the Reserve. The types are described as follows:

Type 1: Typical - These horns are the long, wide flaring variety (Figure 13) which have made the species famous ever since Marco Polo described them in the memorable journal of his travels. Clark (1964) has described the typical hom morphotypes and the reader is referred to this book for a further discussion.

Type 2: Atypical - Although there are no apparent body-size differences between rams of this horn type and that of the other two, the horn lengths and shape differ in that they are shorter, more tightly curled and in some respects resemble more a large bighorn or small Mongolian argali than they do a Marco Polo sheep (Figure 13). 


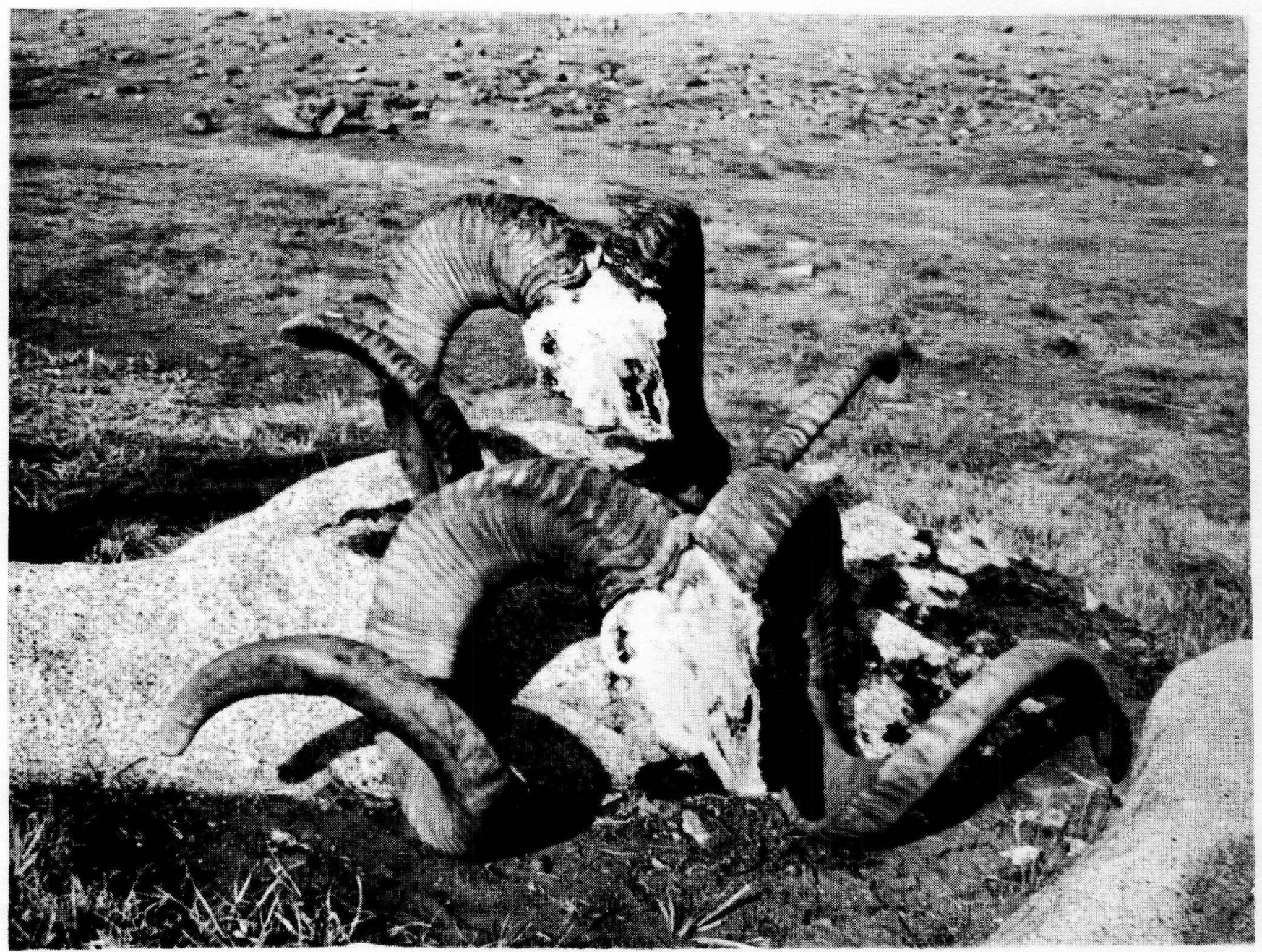

Figure 13. A comparison of the typical and atypical varieties of Marco Polo sheep ram horns. Both individuals shown are nine years old and were shot in 1972 by tourist hunters. The typical wide-flaring horns of the individual below are 60.3 inches in length on the left side; those of the more atypical individual are 52.4 inches, also on the left side. 
Type 3: Attenuated .. These are horns which have been shortened by a removal of their distal portion leaving a smooth stump that can be differentiated from the normally rugose horn surface. The sloughing off of the distal portion of the horn always occurs symmetrically, with both horns attenuated at the same point at the locus of a yearly annulus (Figure 14 and 15). The attenuation has been found to occur among animals as young as four years and up to nine years of age. This type of horn damage has not before been described and is the subject of a paper now being prepared (Shank and Petocz, in prep.). Close studies of these horns suggest a structural rather than a behavioral cause in contrast to the findings of Shackleton and Hutton (1971) for brooming of mountain sheep horns.

Geist (1971) has shown that dominance in wild sheep society is determined by horn size, with the rans possessing the largest horns at the pinnacle of the social hierarchy. A large ram who has lost part of his hom length through the process of attenuation continues to act like a dominant individual, but is not always treated as such by smaller rams in a social context (Shank and Petocz, in prep.). However, it is not yet known what percent of each of these horn types occur within the population. It is hoped that additional studies of the various hom types of Marco Polo sheep will provide this information, a valuable asset in estimating availability of large trophy rams of the more typical (Type 1) class. Frequently annual allowable harvests of horned ungulates are based on total population size, without regard for factors (i.e., trophy standard) on whioh the reputation of the hunt depends. This has been discussed in Fert 3 of this report (FAO, 1978, Project Field Document No. 7). 


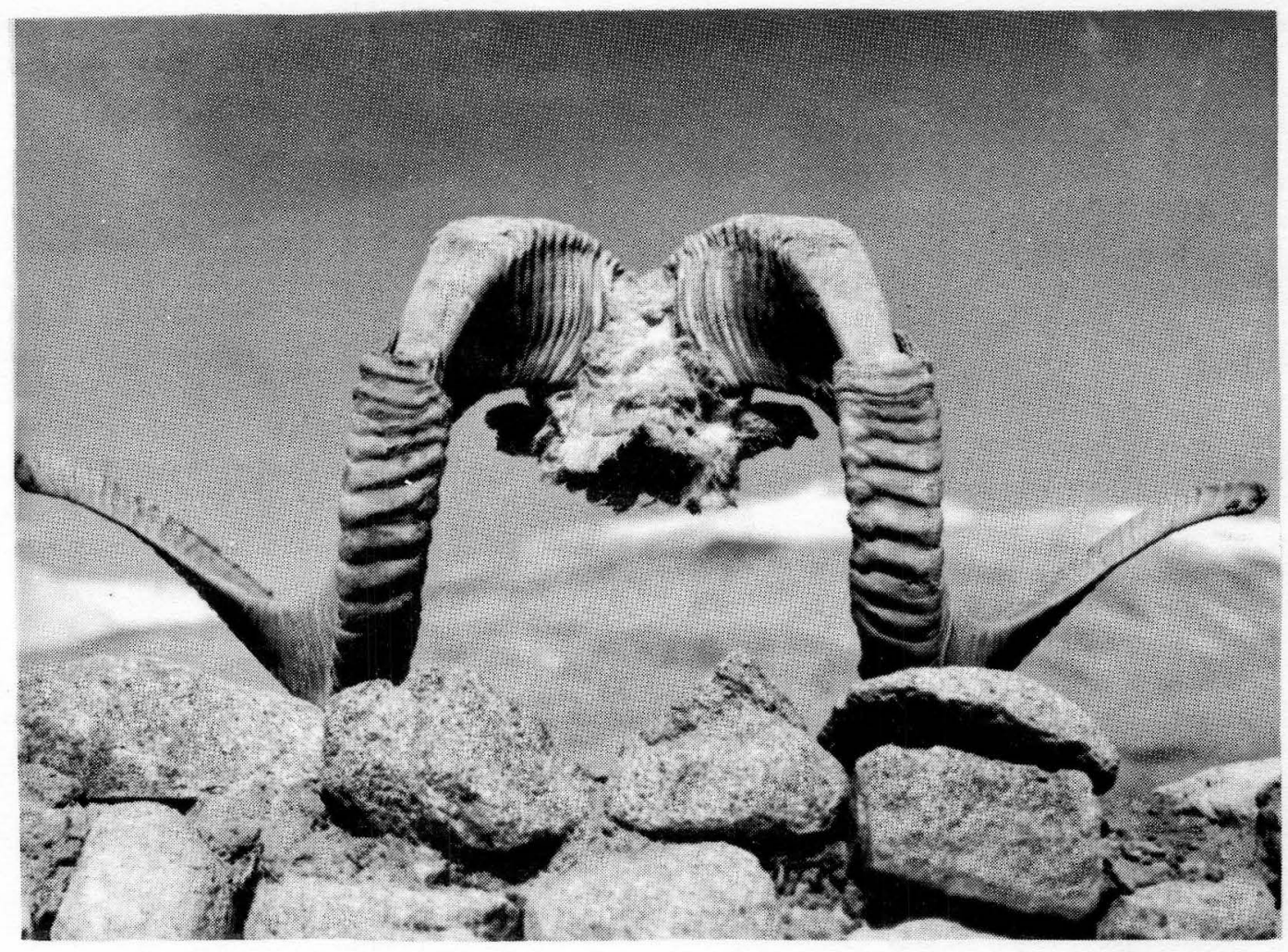

Figure 14. Horn atcenuation on a seven-year-old ram. Note the symmetry of the break which has occurred at the locus of an annulus.

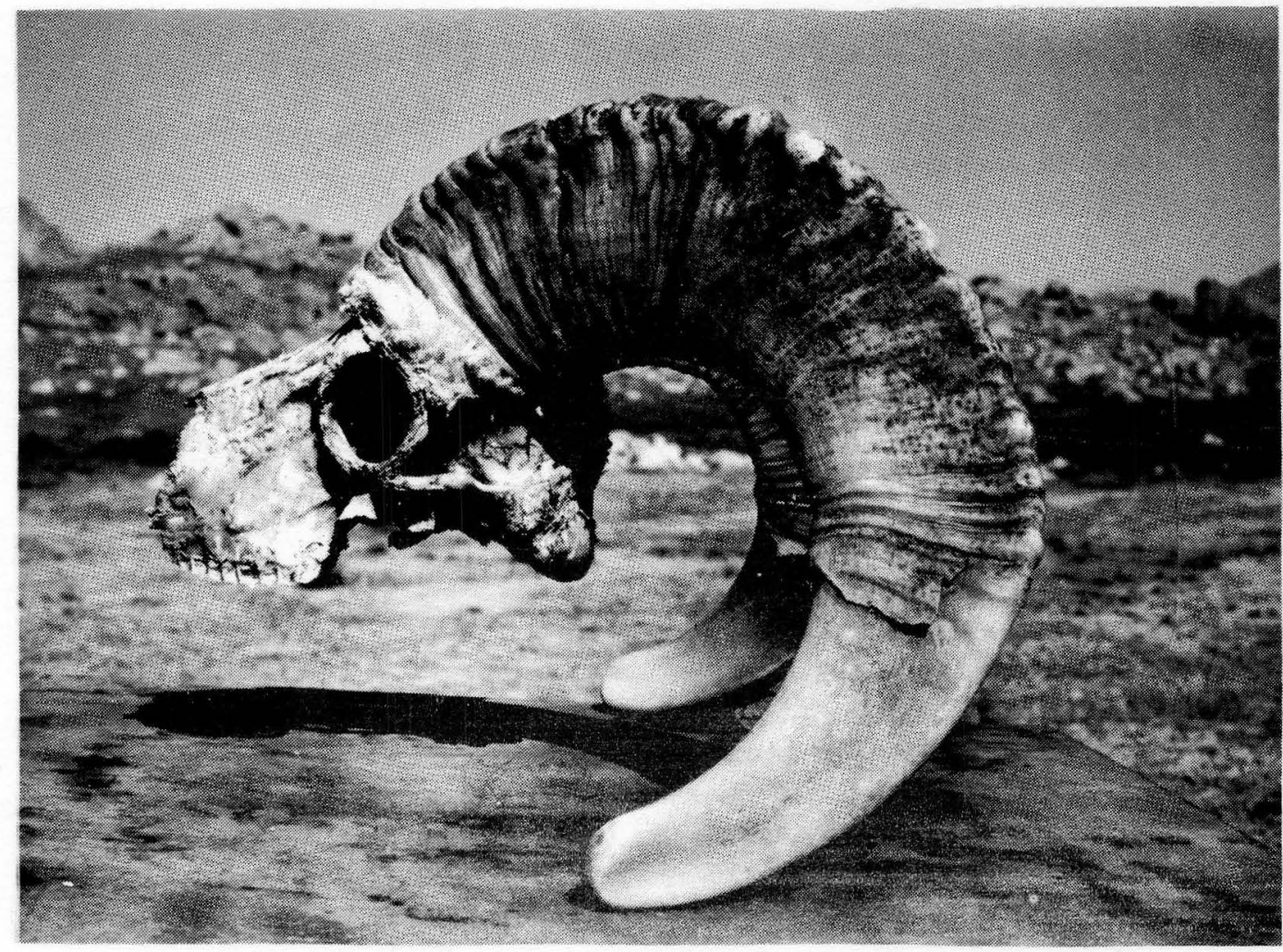

Figure 15. Another example of horns of a mature Marco Polo ram extremely shortened by attenuation. Note the smooth core and symmetry of the original break. 


\section{PREDATION}

Of the carnivores in the area, only two, the wolf (Canis Iupis) and snow leopard (Uncia uncia) are thought to utilize the Maroo Polo sheep as a major prey species. Bear (Ursus arctos), lyn: (tynz lynx) aind fox (Vulpes fulva) prey largely on other species (Egorov, 1965; Saunders, 1963), although both bear and fox have been seen scavenging on caroasses of Marco Polo sheep lilled by wolves.

Petocz and Habibi (1974, pers. obs.) once observed a snow leopard stalking a nursery group of Marco Polo sheep, but unfortunately the animals moved out of sight before the episode was concluded. $\Lambda$ member of the field party saw another snow leopard on Marco Polo sheep rutting range during wi.ter 1975 but no interaction with the sheep was reported.

Other investigators have adequately demonstrated that wolves depend mainly on large mammals for nutrition (Murie, 1944; Cowan, 1947; Pullianen, 1965; Nech, 1966; Pimlott, 1967). Data on wolf predation in the Pamir come largely from observations made during the winter studies of rutting sheep in the Small Pamir by Skogland and Petocz (1975). In a 33-day period, one successful and six unsuocessful stalks by wolves on Marco Polo sheep and ibex were observed and three recently-killed wild sheep carcasses were found in the immediate vicinity of the rutting area (Figure 16). Based on this data sample, it oan be inforred that the wolves in this area hunted with an efficiency of $40 \%$. Only three wolves were observed on the Small Pamir muttinf range, consisting of two adults (possibly a nale-.female coupls) and a single young. Serious stalks were carried out by the two adults. The minimum distance between the wild sheep and wolves vas about $35 \mathrm{~m}$. When the wolves attempted to get closer while in sight of the wild sheep, the sheep would mun in flight. As wolves are known to be territorial (Mech, 1966), other packs probably were excluded from the area. Mech (1966) found that the wolves of Isle Royal which utilized moose (Alces alcos) as their main staple hunted in groups of 7 to 19 animals, while Rawling (1905, in Elton, 1927) stated that the Tibetan wolf hunted gazelles (Gazella subgutterosa) singly, in pairs 


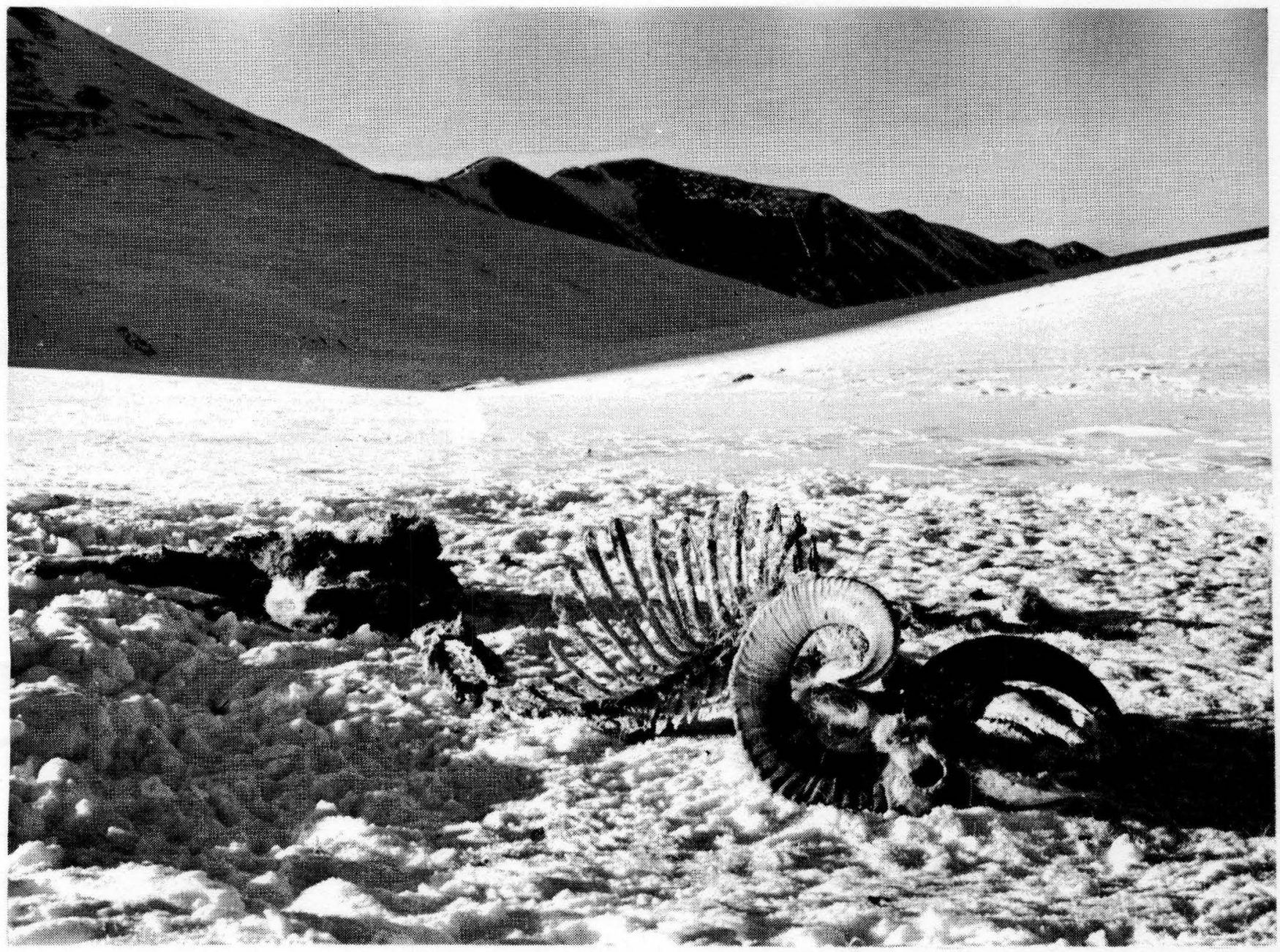

Figure 16. A five-year-old ram killed by wolves on the snow-covered pass of the Jaman Sor rutting area (elevation $4427 \mathrm{~m}$ ). All four wolf kills sighted during the winter scudies in 1974-1975 occurred on similar flat terrain. 
or threes. Since Marco Polo sheep and ibex are intermediate in size between the gazelle and moose, it would therefore appear that wolves in the Pamir who are dependent on these prey species form intermediate pack sizes. The observed three animals is therefore an expected group size for this area. The estimated prey population in the winter study area was 450 animals (about 380 wild sheep and 70 ibex). Therefore, if the assumption that no other wolves are resident in the area is correct, the pack of three wolves could theoretically successfully hunt 36 wild ungulates per annum. This is a predation rate of $8 \%$. However, it is likely that the actual predation rate is at variance with this figure, as the number of sheep and ibex occupying this range fluctuates seasonally because of their traditional range movements in and out of the area.

It was previously suggested that the observed sex ratio in the Small Pamir rutting area may in fact characterize the sheep population in the whole of the Afghan Pamir (Section 4.1.). The male:female ratio of 61:100 indicates a differential mortality between the sexes. Heptner et al. (1951) state that male mountain sheep and ibex suffer disproportionately high winter mortality if they have been very active during the rut. It therefore follows that in populations exposed to wolf predation, there should be a higher proportion of females. This in fact does occur throughout the Afghan Pamix.

These scant drta provide only a limited insight into the relationship of Narco Polo sheep and their major predators. A more meaningful analysis can be provided only after considerable more data are known about the sizes and hunting habits of the major carnivore populatious in the Pamir. 
11. THE PEOPLFS OF THE WAKHAN AND THEIR RELATIONSHIP TO WLARCO POLO SHEHP

\subsection{Distribution}

Figure 17 provides a map of the distribution of the two ethnic groups who inhabit the Walkhan. The Wakhis, a pastoral agricultural society are largely confined to the western half of the Big Pamir, while the pastoral Kirghiz occupy the remainder and majority of the grazing land in the Big and Small Pamir.

\subsection{The Wakhi People}

The Wakhis are a people of mixed origin who have established permanent settlements along the Wakhan River as far east as the village of Sarhad. Here they practice agriculture and cultivate crops of wheat, barley and peas. Fortunately the Wakhan Valley is not used by wild sheep. However, in addition to their agriculture, the wealthier among the population own large numbers of domestic animals which are annually pastured in the high valleys of the Big Pamir mainly during spring and summer months. Rangeland had for years been apportioned among several families and prior to the establishment of the Big Pamir Wildlife Reserve, the system had probably worked well enough. Now these people pasture their animals predominantly in the lower halves of the Big Pamir valleys in the same areas used year-round by female Marco Polo sheep. The resultant competition between female wild sheep and the concentrated grazing pressure of domestic stock, combined with the grazing pressure of wild stock during winter has caused a deterioration of rangeland in this sector (Part 3 of this report, FAO, 1978). Ram territory in valley heads is not disturbed by domestic animals and remains in good condition.

The ill effects of these grazing patterns have been magnified in the female section of the wild sheep population and have produced undesirable trends in the Big Pamir Wildlife Reserve identified and discussed in Section 5.2. 


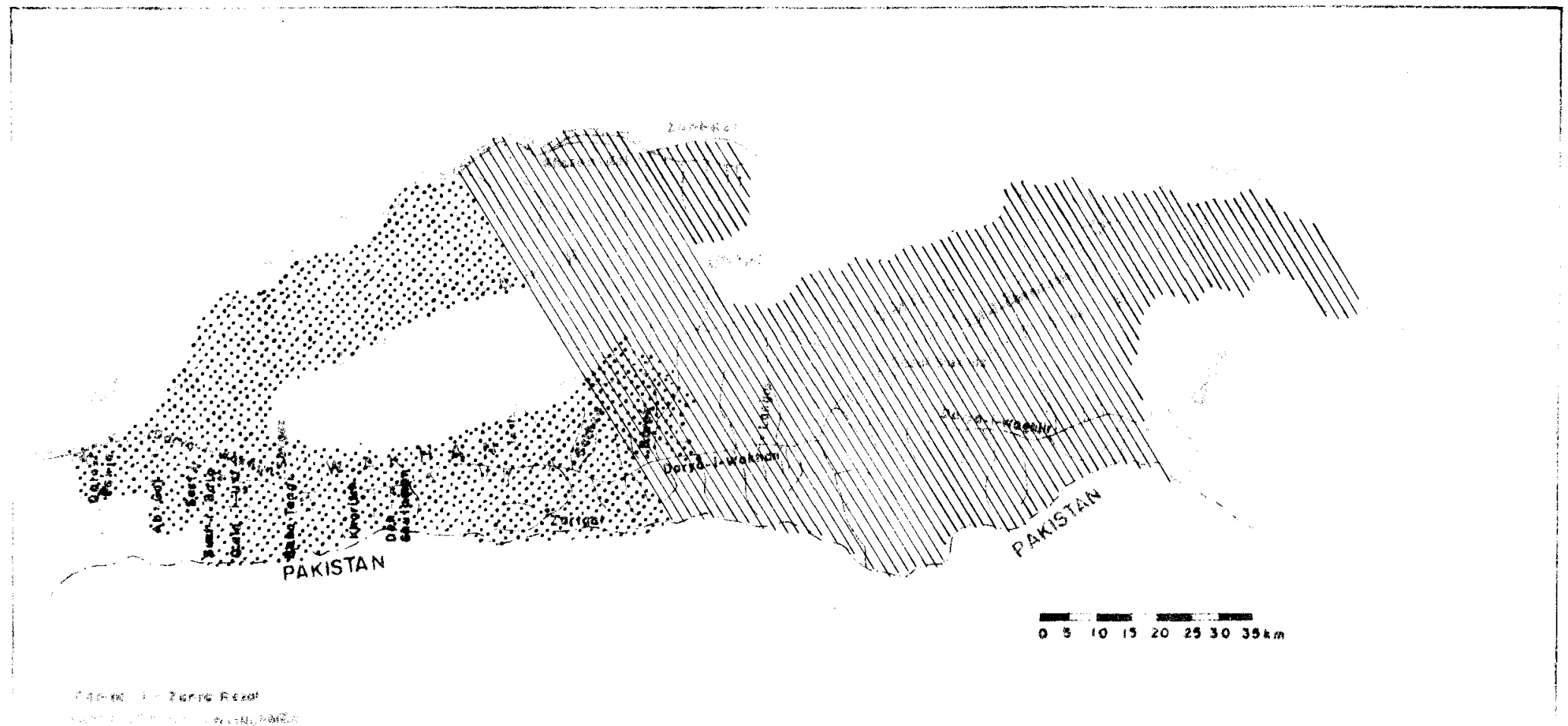

Figure 17. Division of the traditional territories of Wakhi and Kirghiz people in the Afghan Pamir. Legend: -Kirghiz territory. 
Should the current situation persist a decline in lamb production and viability of female sheep can be predicted. Additionally, a decline in hom size among the rams can be expected with adverse effects on government's hunting programme (Part 3 of this report, FAO, 1978).

\subsection{The Kirghiz People}

There is a striking contrast between the Wakhis and Mongol Kirghiz of the eastern Pamir, not only in social and economic status, but also in their pasturing methods and land use. The Kirghiz in Afghanistan are a pastoral, semi-nomadic people. Their livelihood is completely dependent upon their domestic animals - sheep, goats, yaks, and some Bactrian camels. Ample pasturage is therefore of paramount importance and it is perhaps for this reason that they have evolved a system of range usage that maximizes the productivity of the land while at the same tine safeguards it against any severe overutilization.

The Kirghiz are perhaps one of the most feudalistic societien in Afghanistan. Their chieftain (Khan) who resides in the Small Pamir owns about 25000 sheep and goats (Singer, 1976), 2000 yalss, and about 25 Bactrian camels. The remaining etock, about 15000 sheep and goats, 2000 yalss and 70 camels, belongs largely to about a dozen vealthy men. Livestock is apportioned among the 2000 Kirghiz in both the Big and Small Pamir. (Shahrani (19/6) estimates that between 1972-1974 there were 330 households with about 1800 Kirghiz inhabitants in Afghanistar). Family groups maintain these herds throughout the year in traditional areas. Payment for this service is made in dairy products, wool, and live animals. Currency is seldom used. Rangeland is utilized efficiently. Movements between summer and winter areas are slight, and hardly exceed 10 kilometers in most cases. In the Bir Pamir, the people locate higher in to the valleys during summer, and in a series of three or four noves, 
eventually wind up in wintering areas near the Pamir River on the Russian frontier. In the Small Pamir, the south side of the Aksu Valley is used during summer and autumin. By a series of gradual movements, the people arrive at their wintering areas on the north side of the Aksu Valley, and there pasture their animals in the mountainous region bordering the Soviet Union. Deviations from these basic seasonal patterns are not tolerated by the khan or the more wealthy stock owners.

This system of range use, movements, and distribution of livestock is so well conceived and enforced that in both the Big and Small Pamir, the Kirghiz are able to cut and harvest large quantities of sedge (Kobresja and Carex) and grass (Poaceeo) which is stored as supplementary forage for winter. With little exception, the rangeland in the Kirghiz section of the Pamir is $\mid$ probably the best to be found in all of Afghanistail.

\subsection{Hunting by Local People}

Kirghiz hunting, accounts for a considerable harvest of wild sheep. It appears that there are more than 100 Marco Polo sheep and ibex: harvested annually by Kirghiz hunters, most of which takes place in the Small Pamir in the area between the Alssu River and the Soviet frontier. This was substantiated by the nunerous horns found in the area (Table 4 ).

This annual harvest is accomplished in several ways including hunting with firearms (usually .22 calibre) and/or dogs, and an accidental type of hunt where in the course of suarding domestic animals, shepherd dogs encounter and eventually kill a Maroo Polo sheep or ibex or it is otherwise shot by shephards. The wealthy who control most of the domestic animals in the Pamir have expressed the view that wild sheep are undesirable elements on their rangela:d, eating the forage that they require for domestic livestock. Although, hunting is a marginal activity, it is encouraged by stock owners even to the extent of lending a rifle to a poor man to pursue Marco Polo sheep or ivex. 
Hunting, however, is generally non-sclective, with little preference shown for age or sex. Since the most heavily hunted sector which lies in the Small Pamir is occupied more frequently by female Marco Polo sheep than by rams, it follows that many female sheep are killed. This was confirmed in discussions with the Kirghiz and by several observations in the field. Although. most horn material found in the field was that of rams, this does not mean that oily males are taken. ljot only are female remains more difficult to find, but also their skulls and remains are usually consumed by either human or other predators. Skulls of rams cannot be consumed because of their construction, particularly the densely pincunated arca above the brain. The ungulate fossil records from the Pleistocene of Alaska further support this view. Antlers of male cervids attached to slull fragments were frequently found in fossil collections, while female remains were rare to absэnt (Guthrie, pers. commo). Also, shepherd dogs in the Pamir were incapable of consuming any large portion of ram skulls. From the vast number of male skulls found in the field, it is assumed that wolves are likewise incapable of destroying these remains. The skull bones of male cervide are even lighter in construction than those of male mountain sheep.

Kirghiz hunting does not appear a threat to the Marco Polo sheep in the Small Pamir at the present time. On the contrary, since the range resources are good, hunting particularly directed at females has favored a high reproduction and survival of young (Section 5.2.). The wild sheep here show many characteristics of a healthy, exponding population in contrast to counterparts in the Big Pamir Wildlife Reserve.

In the Big Pamir, Wakhi hunting has probably never been a great threat to wildlife populations, as the greater majority of the people are too poor to own firearms. Moreover, a hunting ban has been in effect in that area for about 20 years. Personnel of the Afghan Tourist Organization have for the past 12 years been the overseers of this restriction in connection with their hunting programme for Marco Polo sheep in the Big Pamir. With little exception, the ban has been successfully enforced and will continue into the future. Not more than 12 mature rams are harvested annually in the prograrme 
of the Afghan Tourist Organization, which is of no detriment to this sub-population (Caughley, 1970).

\section{DISCUSSION}

The Marco Polo sheep is clearly a migratory species whish crosses international boundaries. Of the wild sheep found in the Afghan Pamir differences in population quality were reoognized between the animals inhabiting the Big and Small Panirs which are discussed in this report. Further studies are required on the Waghjir Valley population segment before any generalization can be made about this area. However, it appears that the Marco Polo sheep is not a species which is threatened with extinction in this country. The estimated population of 2500 animals which seasonally uses the Afghan Big and Small Pamirs is not unusually large, but it is certainly a viable population.

It is unfortunate, however, that information is lacking on the status of this species in neighboring countries of Pakistan, China, and the Soviet Union. Authorities in Pakistan have stated that the sheep population has declined in their country. This was also the opinion of Schaller (1976). Pislished information on the Marco Polo sheep in China and in the Soviet Union is not readily available. Certainly an exchange of information between these neighboring countries is desireable if we are to obtain a clear picture of the world status and distribution of the Marco Polo sheep. Moreover, close cooperation between these countries is necessary if management efforts are to be coordinated that will compliment individual national efforts and avoid misunderstandings or redundancy. An IUCN-sponsored treaty now in draft, concerned with the management of migratory species, will hopefully involved more of the international community in meaningful cooperative masagement of the world's migratory wildlife. 
RFFERENCES

Bonvalot, G.,1889 - Through the Heart of Asia, over the Pamir to India. Vol. 2, Chapman and Hall Ltd., London.

Caughley, G., 1970 - Report to the Government of Afghanistan on wildlife resources. FAO/UNDP (Report) TA 2905. Rome.

Cherniavski, F.B., 1962 - On the reproduction and growth of the snow sheep (Ovis nivicola Fs,ch. ). Zoologicheskii Zhumal XLI(10):1556-1566. Translation for the Canadian Vildlife Service by G.J. Harder, Canada. Department of the Secretary of State, Bureau of Translations.

Clark, J.L., 1964. - The Great Arc of the Wild Sheep. University of Oklahoma Press, Normain.

Cowan, I. McT., 1947 .. The timber wolf in the Rocky Mountain National Parks of Cenada. Canadian Jour. Res. 25:139-174.

Cumberland, G., 1895 - Sport on the Pamirs. London.

Curzon, G.N॰, 1896 - The Pamirs and the source of the River Ouus. BuIl. Royal Geographical Society, London.

Dunmore, The Earl of, 1893 - The Pamirs. John Murray, London Egorov, O.V., 1965 - Wild Ungulates of Yakutia. Isdatel'stvo "Nauka". Moscow. Translated 1967 by Israel Programme for Scientific Translations. Jerusalem.

Elton, C., 1927 - Animal Ecology. Methuen and Ce., London. Estes, R.D., 1966 - Behavior and life history of the wildebeest. Nature 212:999-1000.

PAO, 1977 - Conservation and utilization of wildlife resources. Afghanistan Interim Report。 Prepared by R.G. Petocz, T. Skogland and K. Habibi. FO:DP/AFP/72/005. FAO, Rome. 
FAO, 1978 - Report on the Afghan Pamir, Part 1, Eoological reoonnaissance. Prepared by R.G. Petocz. Project Field Document No. 5, FO:DP/AFG/74/016.

FAO, 1978 - Report on the Afghan Pamir, Part 3, A management plan for the Big Pamir Wildlife Raserve. Prepared by R.G. Petocz. Project Field Dooument No. 7, FO:DP/AFG/74/016.

Geist, V., 1968 - Film E 1337 Ovis canadensis (Bovidae): Foraging behavior. Eno. Gin. G8ttingen.

Geist, V., 1971 - Mountain Sheep: A study of behavior and evolution. University of Chicago Press, Chicago.

Geist, V. and Petocz, R.G., 1977 - Bighorn sheep in winter: do rams maximize reproductive fitness by spatial and habitat segregation from ewes? Canadian Jour. Z001. 55(11):1802-1810.

Heptner, W.G., A.A. Nasimovitch, and A.G. Bannikov, 1961 - Mammals of the Soviet Union. German translation. Jena: VEB Gustav FishcherVerlag.

Knj.ght, R.G., 1970 - The Sun River elk herd. Wildlife Monographs, no. 23. Komroff, E., 1926 - The travels of Marco Polo. Random House, New York. Kullmann, Ee, 1970 - Die tierwelt Ostafghanistans in ihren geographischen Beziehungen. Freunde des Kolner Z00. 13:3-25

Hech, L.D., 1966 - The wolves of Isle Royal. U.S. Natl. Park Serv., Fauna Ser. no. 7 .

Murie, A., 1944 - The wolves of Mt. Mckinley. U.S. Dept. Interior. U.S. Natl. Park Serv. Fauna Ser. No. 5.

Naumain, C. and J. Niethammer, 1973 - Zur Säugetierfauna des afghanisohen Pamir und des Wakhan. Bonn Zool. Beitr. 24:237-248. 
Petocz, R.G., 1970 - Winter amongst the bighoms. Animals 12(11):520-523. Petocz, R.G., 1971 - The exploitation and conservation of wild ungulates and their habitat in the Afghan Pamir. Report to the Government of Af ghanistan.

Petocz, R.G., 1973 - The effect of snow cover on the social behavior of bighorn rams and mountain goats. Canadian Jour. Zoology 51(9):987-993.

Petooz, R.G., 1973 - Maroo Polo sheep (Ovis ammon poli) of the Afghan

Pamir: A report of biological investigailons in 1972-1973. Report to the Government of Afghanistan.

Petocz, R.G., 1973 - Progress report Number 1 (AFG/72/005): Conservation and utilization of wildifife resourocs. Report to the Government of Afghanistan.

Petocz, R.G. and C.C. Shank, in. prep. - Population differences in Marco Polo sheep (Ovis ammon poli) in the Afghan Pamir.

Petocz, R.G., T. Skogland and C.C. Shank, in. prep. - Winter habitat utilization and diet of Marco Polo sheep (Ovis ammo: poli) in the Small Pamir, Afghanistan.

Pimlott, D.H., 1967 - Wolf predation and ungulate populations. Am. Zoologist $7: 267-273$.

Pullianen, E., 1965 - Studies on the wolf in Finland. Ann. Zool. Fenn. $2: 215-259$.

Saun?ers, J.K., 1973 a Food habits of the lyns in Mewfoundland. Jour. Wildlife Mot. $27(3): 384-390$.

Shank, C.C. and R.G. Petooz, in. prep. - Horn attenuation in Naroo Polo sheep (Ovis ammon poli).

Schaller, G. and Z. Mirza, 1970 - On the behavior of the Punjab urial (Ovis orientatis punjabiensis). Unpubl. Ms. 
Schaller, G., 1976 - Pakistan: Status of wildlife and reserve needs. in Ecological Guidelines for the use of Natural Resources in the Middle East and South West Asia.

Shaoleleton, D.M., 1973 - Population quality and bighom sheep (Ovis canadénsis canadensis SHAW). PhD dissertation. University of Calgary.

Shackleton, D.M. and D.A. Hutton, 1971 - An analysis of the meohanisms of brooming of mountain sheep horms. $Z$. fo Săugertierkunde $6: 342-350$.

Shaw, R.B., 1971 - Visit to High Tartary, Yarkand, and Kashgar and Return Journey Over the Karakorum Pass. John Murray, London.

Singer, A., 1976 - Problems of pastoralism in the Afghan Pamirs. Jour. Asian Affairs v. 63 (new series v. VII) pt. II:156-160.

Skogland, T., 1974 - Villreinens Habitataterd. Roport from the Grazing Committee of the Norwegian IBP.

Skogland, T. and R.G. Petocz, 1975 - Ecology and hehavior of Marco Polo sheep (Óvis ammon poli) in Pamir durinê winter. Repcrt to the Government of Afghanistan.

Struhsaker, T.T., 1967 - Behavior of elk (Cervis canadensis) during the rut. Zeitachrift flir Tierpsycologie 24:80-114。

Wood, J., 1841 - Source of the River Oxus. Blackwood and Sons, London. 